\title{
Deciphering the products of evolution at the species level: the need for an integrative taxonomy
}

\author{
José M. Padial, Santiago Castroviejo-Fisher, Jörn Köhler, Carles Vilà, Juan C. Chaparro \& \\ IgNACio De LA Riva
}

Padial, J. M., Castroviejo-Fisher, S., Köhler, J., Vilà, C., Chaparro, J. C. \& De la Riva, I. (2009). Deciphering the products of evolution at the species level: the need for an integrative taxonomy. - Zoologica Scripta, ${ }^{* *}$, ***_***.

Progress in molecular techniques together with the incorporation of phylogenetic analyses of DNA into taxonomy have caused an increase in the number of species' discoveries in groups with morphological characters that are difficult to study or in those containing polytypic species. But some emerged criticisms plead for a taxonomic conservatism grounded either on the requirement of providing evidences of morphological distinctiveness or reproductive barriers to erect new species names. In a case study of taxonomic research on Neotropical frogs, we combine several lines of evidence (morphological characters, prezygotic reproductive isolation and phylogenetic analyses of mitochondrial DNA) to test the status of 15 nominal species and to assess the degree of agreement of the different lines of evidence. Our study reveals that morphology alone is not sufficient to uncover all species, as there is no other single line of evidence independently. Full congruence between lines of evidence is restricted to only four out of the 15 species. Five species show congruence of two lines of evidence, whereas the remaining six are supported by only one. The use of divergence in morphological characters seems to be the most conservative approach to delineate species boundaries because it does not allow the identification of some sibling reciprocally monophyletic species differing in their advertisement calls. The separate analysis of differences in advertisement calls (evidence of reproductive isolation) or of phylogenetic data alone also shows limitations, because they do not support some morphological species. Our study shows that only an integrative approach combining all sources of evidence provides the necessary feedback to evaluate the taxonomic status of existing species and to detect putative new ones. Furthermore, the application of integrative taxonomy enables the identification of hypotheses about the existence of species that will probably be rejected or changed, and those that can be expected to persist.

Corresponding author: José Manuel Padial, Department of Evolutionary Biology, Evolutionary Biology Centre, Uppsala University, Norbyvägen 18D, SE 75236 Uppsala, Sweden. E-mail: jose.m.padial@ebc.uu.se

Santiago Castroviejo, Department of Evolutionary Biology, Uppsala University, Norbyvägen 18D, 75236 Uppsala, Sweden. E-mail: santiago.castroviejo@ebc.uu.se

Jörn Köhler, Hessisches Landesmuseum Darmstadt, Department of Natural History - Zoology, Friedensplatz 1, 64283 Darmstadt, Germany.E-mail: j.koehler@hlmd.de

Carles Vilà, Estación Biológica de Doñana, CSIC, Avd. María Luisa s/n, 41013 Sevilla, Spain. E-mail: carles.vila@ebd.csic.es

Juan C. Chaparro, Museo de Historia Natural, Universidad Nacional de San Antonio Abad del Cusco, Cusco, Peru. E-mail: jchaparroauza@yahoo.com

Ignacio De la Riva, Department of Biodiversity and Evolutionary Biology, Museo Nacional de Ciencias Naturales, CSIC, C/José Gutiérrez Abascal 2, 28006 Madrid, Spain. E-mail: iriva@mncn.csic.es

\section{Introduction}

Almost 60 years after the proposal of the evolutionary species concept (Simpson 1951), systematists are only recently accepting that species are temporal segments of separately evolving lineages (Wiens 2007). The lineage concept implies that the only necessary and sufficient property for an entity to be a species is that it corresponds to a temporal segment of a populational or metapopulational lineage evolving 
separately from other lineages, and that no trait alone (e.g. reproductive incompatibility, morphological differentiation, etc.) can be considered as a biological property that a species must show to be recognized as such (Wiley 1978; Frost \& Kluge 1994; Mayden 1997, 2002; de Queiroz 2005a,b,c, 2007). The fundamental implication of the evolutionary (or lineage) concept for taxonomy is that it allows breaking operational circularity because no single suit of characters can now be defended as the best line of evidence to reveal species (as separate biological entities) or to assess the status of nominal species. Any kind of evidence can, therefore, be used to propose an initial hypothesis. Evidences or tests that are different from those used for proposing the initial hypothesis can be brought up to try to corroborate it (Faith \& Trueman 2001; Faith 2004). If a species is described, for example, on the sole basis of morphology, by providing additional lines of evidence through different operational methods with different underlying assumptions, as phylogenetic analyses of DNA or analyses of reproductive barriers, we can gain confidence in our species (De Queiroz 2007) and escape circularity (Desalle et al. 2005). This has been routinely performed by many taxonomists when new approaches based on new suites of evidence (e.g. allozymes, DNA, ecological niche data, advertisement calls) were analysed, but commonly without an explicit acceptance of the conceptual framework provided by the evolutionary species concept. Thus, incongruence among lines of evidence was commonly interpreted either as evidence of erroneous taxonomic hypotheses or of the intrinsic limitations of particular concepts, methods or characters (Sites \& Marshall 2004). Under this species concept, incongruence is expected as biological properties of lineages never arise in a given particular order or quantity (Wiley 1978, 1981).

The framework provided by the lineage concept is being rapidly accepted by most phylogeneticists and population biologists who aim at delineating species boundaries (Wiley 1981; Wiens \& Penkrot 2002; Funk \& Omland 2003; Hey et al. 2003; Sites \& Marshall 2004; Wiens 2007; Knowles \& Carstens 2007), and gradually by some taxonomists (Dayrat 2005; Padial \& De la Riva 2006; Agnarson \& Kuntner 2007). Dayrat (2005) labelled the taxonomic research that explicitly accepts the implications of the evolutionary species concept as 'Integrative Taxonomy'.

Integrative taxonomists who use new and disparate lines of evidence to discover and support species have, nevertheless, not escaped criticism. For example, the rapid increase in the number of morphological species being reassessed by the application of DNA-based taxonomy (Agapow et al. 2004) has led to many taxonomic changes that are not well-received by some users of species names, who see their comparative units changing or their funds becoming insufficient for species-specific conservation plans (e.g. Isaac et al. 2004;
Meiri \& Mace 2007). Integrative taxonomists have also been criticized by those taxonomists who either show explicit preference for morphological characters (e.g. Valdecasas et al. 2008), and/or are also afraid that funding initially destined to morphological taxonomic revisions might be deviated towards funding DNA taxonomy or DNA barcoding (e.g. Wheeler 2005, 2007). Others have even launched the proposal of promoting taxonomic conservatism following arbitrary criteria of morphological distinctness and reproductive isolation to accept changes or the erection of new species names (e.g. Meiri \& Mace 2007).

We provide a review of our own taxonomic research on Bolivian and southern Peruvian frogs of the genus Pristimantis (Amphibia: Anura, Strabomantidae) to illustrate how the use of a single line of evidence would have not allowed the discovery of all species considered. We show how combining several sources of evidence flags taxonomic problems that are in need of special attention, and identifies which species hypotheses can be expected to persist with some stability and which are most likely to change their status or to be rejected. We evaluate the reliability of species through a reanalysis of their morphological characters, by exploring differences in their advertisement calls (as evidence of prezygotic reproductive isolation), and by evaluating their monophyly through phylogenetic analyses of a fragment of the mitochondrial DNA (mtDNA) 16S gene, a sequence commonly used in DNA taxonomy of frogs (Köhler et al. 2005; Vences et al. 2005).

Comparing different lines of evidence to test species in the genus Pristimantis is challenging. With approximately 400 species currently recognized, it represents the most speciesrich monophyletic genus of terrestrial vertebrates (Hedges et al. 2008). Pristimantis shares the burdening characteristics of many taxonomically complex tropical groups: individuals are difficult to detect (resulting in few sampled individuals for species descriptions), they possess subtle morphological differences, and commonly show high levels of intraspecific polymorphism. Thus, although our example is restricted to frogs, it probably mirrors similar situations in many other groups of tropical organisms.

In short, this study shows that an integrative taxonomy grounded on evolutionary theory is necessary to accomplish a reliable inventory of Earth's biodiversity.

\section{Materials and methods}

A total of 26 species of Pristimantis are currently known for the Amazonian versant of the Andes and adjacent lowlands from central Bolivia to southern Peru (Padial et al. 2004; Duellman 2005; Padial \& De la Riva 2009), all of them belonging to three morphologically well-distinguished supraspecific taxa: the subgenus Yunganastes (monophyletic), the Pristimantis conspicillatus species group (monophyletic) and the $P$. unistrigatus species group. The latter is non-monophyletic 
because the pair $P$. llojsintuta and $P$. platydactylus belongs to this group (see Fig. 1). The subgenus Yunganastes contains five species endemic to the Andes of central Bolivia and southern Peru (Padial et al. 2007). The P. unistrigatus and $P$. conspicillatus groups are species-rich taxa with members occurring in the Andes and the Amazon basin from central Bolivia to northern South America (Frost 2007; Hedges et al. 2008).

For this study, we compared the external morphology of 1538 specimens belonging to the 26 species (including type specimens) occurring in the Amazonian versant of the Andes and adjacent lowlands from central Bolivia to southern Peru belonging to these three supraspecific taxa (see Appendix 1 for a list of specimens studied for each species). We thus assessed both, the accurateness of the original description and the validity of each species based on morphological characters. In other words, we evaluated that each species has diverged in morphology from all other species occurring in the area. We also compared the advertisement calls of 14 of these species to determine whether prezygotic reproductive barriers were likely to exist. Finally, we performed phylogenetic analyses of a fragment of the $16 \mathrm{~S}$ mtDNA gene to assess their monophyly in this gene genealogy. Our data set allows us to test the status of 15 species of Pristimantis for which at least two lines of evidence were available (Table 1).

\section{Morphology}

To determine the degree of morphological divergence among species, we investigated ten external qualitative characters (see Appendix 2 for characters and states) that are broadly used to describe Pristimantis species (Lynch \& Duellman 1997; Köhler 2000a; Duellman 2005; Padial \& De la Riva 2009). Following Wiens \& Servedio (2000), if a trait is putatively fixed in a sample of at least ten specimens, there is at least a $95 \%$ probability that the trait is fixed for the species. With exception of P. ashkapara, for which < 10 specimens are known (Köhler 2000b; Padial et al. 2007), we always examined more than ten (Appendix 1).

We consider that a species shows divergence in morphology when exhibiting at least one fixed character state not shared with each of the other species. The underlying assumption is that fixed differences in morphology might be strong evidence of reduced or absent gene flow (Wiens \& Servedio 2000), and those differences usually coincide with separate units defined by reproductive gaps (Rieseberg et al. 2006) and molecular divergences (Avise \& Deette 1999), constituting thus evidence of lineage divergence. We compiled a data matrix with all characters and states and reconstructed a Neighbor-joining dendrogram with the exclusive aim of providing a way to visualize the degree of overlap. We did not intend to reconstruct phylogenetic relationships or to estimate character distances between species.

\section{Reproductive barriers}

Information about advertisement calls for Pristimantis was extracted from published descriptions (Table 2). A detailed description of methods used for call analyses and terminology of characters can be found in Köhler (2000a) and Padial et al.

Table 1 Bolivian and Peruvian species of Pristimantis included in this study and lines of evidence supporting (Yes) or not (No) the species hypotheses.

\begin{tabular}{|c|c|c|c|c|c|}
\hline & Original description & Morphology & Mating call & Monophyly & Taxonomic status \\
\hline P. ashkapara (Köhler, 2000) & Call & No & Yes & Yes & Stable \\
\hline P. bisignatus (Werner, 1899) & Morphology & Yes & Yes & Yes & Stable \\
\hline P. buccinator (Rodríguez, 1994) & Morphology & Yes & No & Yes & Stable \\
\hline P. danae (Duellman, 1978) & Morphology & No & Yes & No & Stable \\
\hline P. fenestratus (Steindachner, 1864) & Morphology & Yes & No & No & Stable \\
\hline P. fraudator (Lynch and McDiarmid, 1987) & Morphology & Yes & Yes & Yes & Stable \\
\hline P. koehleri (Padial and De la Riva, 2008) & Morphology call, mtDNA & Yes & No & No & Stable \\
\hline P. Ilojsintuta (Köhler and Lötters, 1999) & Call & No & Yes & Yes & Instable \\
\hline P. mercedesae (Lynch and McDiarmid, 1987) & Morphology & Yes & - & Yes & Stable \\
\hline P. platydactylus (Boulenger, 1903) & Morphology & No & Yes & No & Instable \\
\hline P. pluvicanorus (De la Riva and Lynch, 1997) & Morphology & No & Yes & Yes & Stable \\
\hline P. reichlei (Padial and De la Riva, 2008) & Call, mtDNA & No & Yes & No & Stable \\
\hline P. rhabdolaemus (Duellman, 1978) & Morphology & Yes & Yes & Yes & Stable \\
\hline P. samaipatae (Köhler and Jungfer, 1995) & Morphology & Yes & No & Yes & Stable \\
\hline P. toftae (Duellman, 1978) & Morphology & Yes & Yes & Yes & Stable \\
\hline
\end{tabular}

Original description indicates main evidence used to describe the species. Morphology indicates if the species has diverged or not in at least one fixed character state (see text, Fig. 2 and Appendix 2). Advertisement call indicates if the species' advertisement call shows a distinctive structure or does not overlap in quantitative characters with those in other species (Table 2). Monophyly indicates if there is significant Bayesian support for the monophyly of the species, reconstructed using a 528-bp fragment of the mtDNA 16S gene (Fig. 1; for the species P. ashkapara and P. fraudator only one specimen was sequenced). Taxonomic status indicates recommended degree of stability that can be expected from the nominal species (see text). 


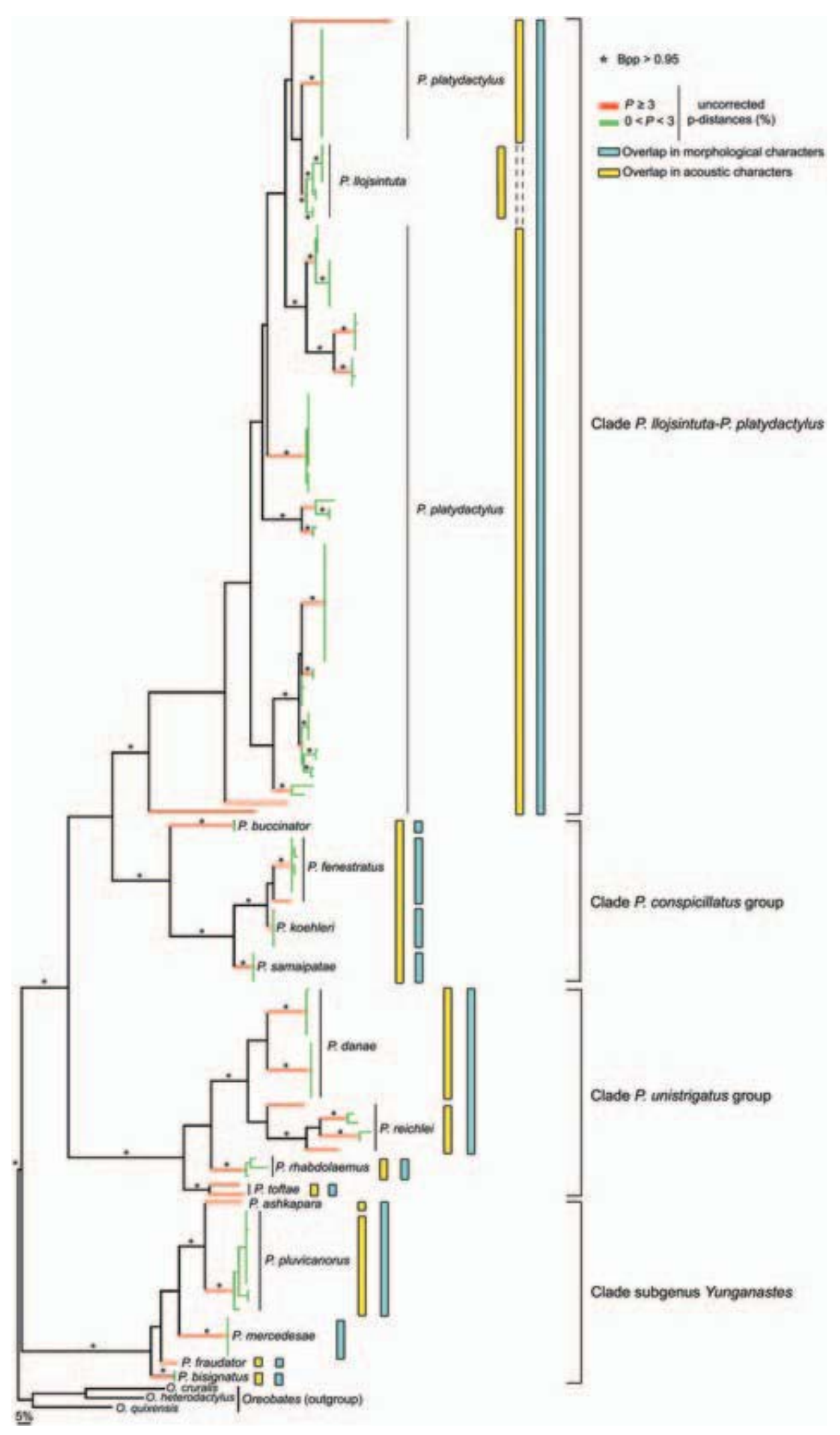


Table 2 Advertisement call characteristics, sample sizes and data sources for 14 species of Pristimantis from Bolivia and southern Peru.

\begin{tabular}{|c|c|c|c|c|c|c|c|c|c|c|}
\hline \multirow[b]{2}{*}{ Species } & \multicolumn{10}{|c|}{ Acoustic characters } \\
\hline & Call type & Notes/call & Note length (ms) & Number of pulses & $\begin{array}{l}\text { Dominant } \\
\text { frequency }(\mathrm{Hz})\end{array}$ & Notes & s Calls & Individual | & I Population & Source \\
\hline \multicolumn{11}{|c|}{ P. conspicillatus group } \\
\hline P. buccinator & Pulsed & $1-6$ & $50-66$ & $17-18$ & $3564-3660$ (3595) & - & 6 & - & 1 & Rodríguez (1994) \\
\hline P. fenestratus & Pulsed & $2-4(2.6 \pm 0.6)$ & $50.0-91.0(63 \pm 11.4)$ & $9-17(12.9 \pm 42.2)$ & $\begin{array}{l}1710-3591 \\
(3086.3 \pm 580.7)\end{array}$ & 55 & 22 & 6 & 4 & $\begin{array}{l}\text { Padial \& De la } \\
\text { Riva (2008) }\end{array}$ \\
\hline P. koehleri & Pulsed & $3-8(5.7 \pm 1.0)$ & $20-54(35.5 \pm 6.6)$ & $5-9(7.5 \pm 1)$ & $\begin{array}{l}3245-3971 \\
(3662.4 \pm 128.9)\end{array}$ & 119 & 21 & 6 & 2 & $\begin{array}{l}\text { Padial \& De la } \\
\text { Riva (2008) }\end{array}$ \\
\hline P. samaipatae & Pulsed & $1-3(2 \pm 0.2)$ & 59-141 (89 \pm 16.4$)$ & $11-23(16.4 \pm 2.6)$ & $\begin{array}{l}2922-3853 \\
(3326.7 \pm 175.9)\end{array}$ & 160 & 98 & 12 & 4 & $\begin{array}{l}\text { Padial \& De la } \\
\text { Riva (2008) }\end{array}$ \\
\hline \multicolumn{11}{|c|}{ P. unistrigatus group } \\
\hline P. danae & Pulsed & 1 & $7-13(11 \pm 1.2)$ & $1-2(1.9 \pm 0.2)$ & $\begin{array}{l}1369-2925 \\
(2210 \pm 553.4)\end{array}$ & 87 & 87 & 4 & 2 & $\begin{array}{l}\text { Padial \& De la } \\
\text { Riva (2008) }\end{array}$ \\
\hline P. llojsintuta & Non-pulsed & $5-6$ & $7-14(9.9 \pm 2.5)$ & 0 & $\begin{array}{l}2588-2973 \\
(2746.3 \pm 122.7)\end{array}$ & 54 & 6 & 3 & 2 & $\begin{array}{l}\text { Köhler \& Lötters (1999) } \\
\text { Unpublished data }\end{array}$ \\
\hline P. platydactylus & Non-pulsed & $1-6$ & $2.7-5.6(3.7 \pm 0.9)$ & 0 & $\begin{array}{l}2342.3-2927.9 \\
(2642.7 \pm 178.9)\end{array}$ & - & 16 & 1 & 1 & Márquez et al. (1995) \\
\hline P. reichlei & Pulsed & $2-3$ & $20-58(32 \pm 5.8)$ & $4-11(6.7 \pm 1.2)$ & $\begin{array}{l}2013-2815 \\
(2501.4 \pm 197.7)\end{array}$ & 137 & 63 & 5 & 3 & $\begin{array}{l}\text { Padial \& De la } \\
\text { Riva (2008) }\end{array}$ \\
\hline P. rhabdolaemus & Non-pulsed & 1 & $13-22(19.0 \pm 2.5)$ & 0 & $\begin{array}{l}2870-3650 \\
(3117 \pm 296)\end{array}$ & 22 & 22 & 4 & 1 & Köhler (2000a) \\
\hline P. toftae & Pulsed & 1 & $\begin{array}{l}15.1-23.9 \\
(20.5 \pm 3.7)\end{array}$ & $2-3$ & $\begin{array}{l}4765.4-4967.3 \\
(4874.4 \pm 4967.3)\end{array}$ & 5 & 5 & 2 & 1 & Márquez et al. (1995) \\
\hline \multicolumn{11}{|c|}{ Subg. Yunganastes } \\
\hline P. ashkapara & Non-pulsed & 1 & $24-43(36.0 \pm 5.9)$ & 0 & $\begin{array}{l}1454-1493 \\
(1476 \pm 11)\end{array}$ & 43 & 43 & 2 & 1 & Padial et al. (2007) \\
\hline P. bisignatus & Non-pulsed & 1 & $16-25(20.8 \pm 2.7)$ & 0 & $\begin{array}{l}1182-1275 \\
(1220 \pm 37)\end{array}$ & 25 & 25 & 2 & 1 & Padial et al. (2007) \\
\hline P. fraudator & Non-pulsed & 1 & $5-9(6.5 \pm 0.8)$ & 0 & $\begin{array}{l}1547-1712 \\
(1624 \pm 39)\end{array}$ & 60 & 60 & 1 & 1 & Jansen \& Köhler (2007) \\
\hline P. pluvicanorus & Non-pulsed & 1 & $210-440(310.5 \pm 72.2)$ & 0 & $\begin{array}{l}1348-1361 \\
(1356 \pm 5)\end{array}$ & 25 & 25 & 1 & 1 & $\begin{array}{l}\text { Köhler (2000b); } \\
\text { Padial et al. (2007) }\end{array}$ \\
\hline
\end{tabular}

Mean \pm SD follows range between parentheses.

(2008b). Among the species considered, only the call of $P$. mercedesae is unknown. Sample sizes did not allow for temperature and body size corrections.

Advertisement call differences are usually interpreted as evidence of lineage divergence that can be used to discover species (Bickford et al. 2007; Vences \& Wake 2007; Padial et al.2008a,b). The underlying assumption is that differences in advertisement calls evidence the likely existence of prezygotic reproductive barriers (Gerhardt 1994; Ryan \& Kime 2003), because the neurological structure controlling the female auditory system is adapted to detect and select calls of conspecific males (Ryan 1988). The suggestion of prezygotic reproductive barriers should not be confounded with evidence of reproductive incompatibility, because species showing differences in advertisement call can and do hybridize (Pfennig 2007). We consider that advertisement calls conclusively indicate the existence of prezygotic reproductive barriers when they show structural differences (pulsed vs. non-pulsed) or do not overlap in quantitative parameters (note length, call length, number of notes per call, number of pulses and dominant frequency).

\section{Monophyly and genetic distances}

To assess the monophyly and calculate genetic distances, we used a 528-base pair (bp) fragment of the $16 \mathrm{~S}$ gene of the mtDNA. This fragment has been broadly used for DNA

Fig. 1 Bayesian phylogenetic tree of a 528-bp fragment of the 16S mtDNA gene for 154 terminals of 15 recognized species of Pristimantis from Peru and Bolivia plus three outgroup taxa of the genus Oreobates. Asterisks indicate Bayesian posterior probability $\geq 0.95$. Red branches indicate specimens or populations showing genetic divergences (uncorrected $P$ ) higher than $3 \%$. Green branches indicate genetic divergences lower than $3 \%$. Yellow bars indicate overlap in acoustic characters and blue bars indicate overlap in morphological characters. 
taxonomy (Vences et al. 2005; Fouquet et al. 2007) and phylogenetics (Darst \& Cannatella 2004; Frost et al. 2006) of tropical anurans, including Pristimantis (Fouquet et al. 2007; Padial et al. 2007; Hedges et al. 2008). Our data set included 154 terminals of the 15 nominal species plus three outgroup taxa of the basal genus Oreobates (Hedges et al. 2008; Padial et al. 2008b). Tissue fragments were obtained from specimens avoiding any damage to structures and organs used for morphological analyses. Tissue samples and extractions are preserved at the public DNA and tissue collection of the Museo Nacional de Ciencias Naturales (Madrid, Spain). DNA sequences for specimens of the nominal species $P$. platydactylus, $P$. llojsintuta and $P$. buccinator were produced for this study, the rest of sequences corresponded to those reported by Padial \& De la Riva (2009) and Padial et al. (2007, 2008b). Specimens, locality, original publication and GenBank accession numbers are listed in Appendix 3.

Genomic DNA was extracted from ethanol-preserved tissues using standard phenol-chloroform extraction protocols (Sambrook et al. 1989). The 16S fragment was amplified and sequenced using the universal primers 16Sar-5' and 16Sbr-3' (Hillis et al. 1996). The polymerase chain reaction (PCR) amplification protocols were as follows: $95{ }^{\circ} \mathrm{C} / 15 \mathrm{~s}$; 35 cycles of $95{ }^{\circ} \mathrm{C} / 30 \mathrm{~s}, 50{ }^{\circ} \mathrm{C} / 30 \mathrm{~s}, 72{ }^{\circ} \mathrm{C} / 1 \mathrm{~min}$ and $72{ }^{\circ} \mathrm{C} / 10 \mathrm{~min}$. PCR products were visualized in agarose gels, and unincorporated primers and dNTPs were removed from PCR products using ExoSap purification (ExoSap-it, GE Healthcare). Cycle sequencing reactions were completed using the corresponding PCR primers and BigDye Terminator 3.1 chemistry (Applied Biosciences), with a standard cycle sequencing profile $\left(96{ }^{\circ} \mathrm{C} / 3 \mathrm{~min}\right.$; 35 cycles of $96{ }^{\circ} \mathrm{C} / 10 \mathrm{~s}$, $50{ }^{\circ} \mathrm{C} / 15 \mathrm{~s}, 60{ }^{\circ} \mathrm{C} / 3 \mathrm{~min}$ and $\left.72{ }^{\circ} \mathrm{C} / 7 \mathrm{~min}\right)$. Reaction products were purified using ethanol precipitation and run in an $\mathrm{ABI}$ 3730xl analyser. Data from two complementary strands were compared to generate a consensus sequence for each DNA fragment using Sequencher 4.1 (Gene Codes Corp. 2000). The 16S fragment was aligned with the software Mafft (Katoh et al. 2005) under the L-INS-i strategy and default parameters. We used the program modeltest 3.7 (Posada \& Crandall 1998) to select the model of sequence evolution that best fits the data. The model and the parameter estimates were chosen by Akaike's information criterion (Akaike 1974). The chosen model was General Time Reversible model with a proportion of invariable sites and a gamma-shaped distribution of rates across sites (GTR $+\mathrm{I}+\Gamma$ ). For Bayesian phylogenetic analyses (Rannala \& Yang 1996), we used MrBayes version 3.2.1 (Huelsenbeck \& Ronquist 2001). The majority rule consensus tree was produced from two independent runs, each with one cold (the head chain) and three heated Monte Carlo Markov chains (MCMC) (Yang \& Rannala 1997), run for 10 million generations (Metropolis-coupled MCMC). Trees were sampled every
1000 generations. Burn-in was evaluated by examination of the standard deviation of split frequencies and the likelihood-lnL. Clades with posterior probabilities $\geq 0.95$ are considered supported, but we caution that relatively high posterior probabilities for short internodes may be over-estimates of confidence (Alfaro et al. 2003; Erixon et al. 2003). Monophyly was assessed from the Bayesian phylogenetic tree. In addition, to test the degree of congruence in number of species following the 3\% threshold of genetic divergence recommended by Fouquet et al. (2007) for Neotropical anurans, we calculated genetic distances among species using Paup* 4.0b10 (Swofford 1998). The monophyly analyses are based on the assumption that coalescent patterns in gene genealogies are related to historical processes that originate separate lineages (Avise \& Deette 1999; Avise 2000; Templeton 2001; Hewitt 2004; Knowles \& Carstens 2007).

\section{Results and discussion \\ Discordance of lines of evidence}

Our analysis shows that no particular line of evidence supports all of the 15 currently accepted species for which at least two lines of evidence were available. Because all are supported by at least one, none of them can be rejected. Only 4 of the 15 nominal species (27\%) have diverged in morphology and prezygotic reproductive barriers and are monophyletic. Six other species show congruence in two lines of evidence, whereas the remaining five species are supported by only one (Table 1, Fig. 1).

Of the 26 nominal species analysed for morphological divergences, 13 overlap in character states (Fig. 2, Appendix 2). Only nine of the 15 species selected for the comparison of the different lines of evidence have diverged in morphological characters, although 11 of them were originally described on the basis of morphology only (Table 1). Moreover, our analysis of morphological divergence seems to be the most restrictive approach because it does not allow the discovery of some sibling monophyletic species well-distinguished by their advertisement calls (e.g. P. ashkapara and P. pluvicanorus). Six species that are not supported by morphology are supported by acoustic characters, and three others are supported by monophyletic.

The use of evidence of prezygotic reproductive barriers also shows some limitations. Only ten of the 14 named species for which this line of evidence is available were unequivocally distinct in their advertisement calls (Table 2, Fig. 1). Four species not supported by acoustic characters ( $P$. buccinator, $P$. fenestratus, $P$. koehleri and $P$. samaipatae) were monophyletic and show divergences in morphology.

Phylogenetic analyses also did not support the monophyly of all named species. Only ten were supported (Fig. 1, Table 1; for two of the species only one specimen was sequenced). 


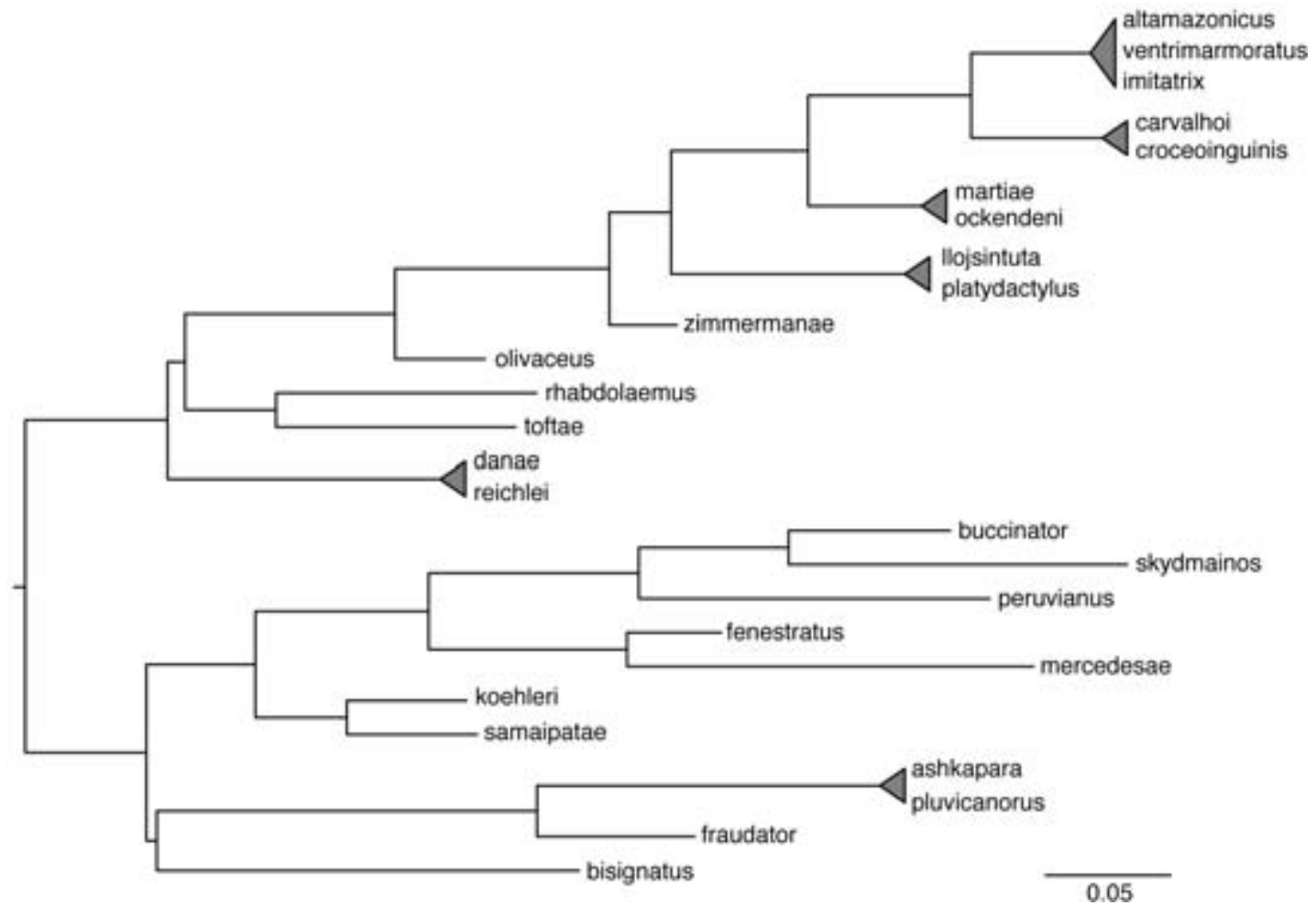

Fig. 2 Neighbor-joining dendrogram showing the degree of overlap in character states for ten qualitative morphological characters (Appendix 2) of 26 species of Pristimantis inhabiting the Andes and adjacent Amazonian lowlands of Bolivia and southern Peru. Terminal triangles indicate complete coincidence in characters states.

For example, two morphologically similar species showing prezygotic reproductive barriers ( $P$. danae and $P$. reichlei), and two others morphologically divergent ( $P$. koehleri and $P$. fenestratus) did not receive support for their reciprocal monophyly. In another case, one nominal species (P. llojsintuta) was nested within another one (P. platydactylus).

\section{The meaning of discordance of lines of evidence}

Discordance among lines of evidence does not imply that a species hypothesis is invalid. Only the absence of divergence can be used to group two species (Wiley 1981). Discordance may indeed reflect either sampling biases (e.g. the selected characters did not reflect existing divergences; inadequate sampling across populations, etc.), or the decoupling of character evolution during the divergence of lineages (Smith et al. 2005; Lougheed et al. 2006). In the case of sampling biases, conciliation of disparate evidences may only require the reassessment of range limits (Heckman et al. 2006), or reanalysis of characters or original data sets to discover if one or more species were included in the analyses (Page et al. 2005). In case of decoupling of characters, incongruence of lines of evidence is expected, and can be due to faster divergence in some characters than in others, promoted by different evolutionary processes (Orr \& Smith 1998). For example, rapid adaptive radiations can result in morphologically divergent species with low levels of genetic differentiation (Cunha et al. 2005). Despite gene flow, selective pressures may result in higher rates of morphological divergence in parapatric populations occupying different habitats than those found among populations isolated for millions of years and even among species (Smith et al. 2005). In other cases, genetic drift could promote rapid genetic differentiation despite morphological stasis (Sturmbauer \& Meyer 1992).

Meiri \& Mace (2007) suggested, however, that for recognizing a valid species 'a quantitative comparative approach should show [...] that the degree of observed differences is similar to differences observed between closely related sympatric (i.e. geographically overlapping) species'. They thus try to establish a measure of morphological divergence associated to reproductive isolation that would allow them to decide between what is and what is not a species. But our analysis, together with the examples above, shows that comparable degrees of divergence cannot be expected even for closely related species. For example, sister sympatric species (as P. ashkapara and 


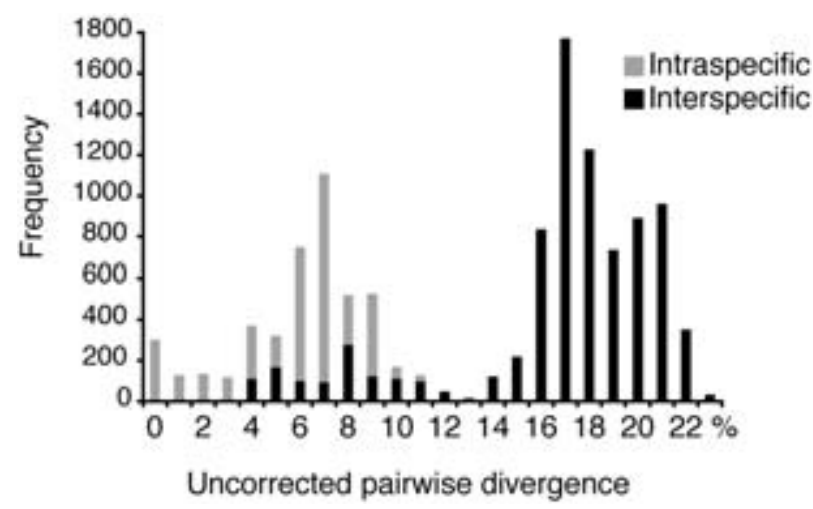

Fig. 3 Interspecific and intraspecific genetic divergences (uncorrected $P$ ) in a 528-bp fragment of the $16 \mathrm{~S}$ mtDNA gene for 154 terminals of 15 species of Pristimantis from Peru and Bolivia (see Fig. 1).

P. pluvicanorus) can be morphologically identical in qualitative characters, even if they have diverged in their mating calls. Other species (as $P$. buccinator) are morphologically very divergent even if they have not developed prezygotic reproductive barriers and inhabit in allopatry from its most closely related species. In cases of parapatry, closely related species may have scarcely diverged in morphology and prezygotic reproductive barriers and be reciprocally non-monophyletic because of recent divergence after colonizing new habitats through dispersion (Funk \& Omland 2003). This seems to be the case for P. koehleri, $P$. fenestratus and P. samaipatae. Other species in the same situation (as $P$. danae and $P$. reichlei), however, might have evolved strong differences in their prezygotic reproductive barriers.

The use of thresholds of genetic distances to delineate species Fouquet et al. (2007) recently suggested a minimum of $3 \%$ of genetic divergence (uncorrected $P$ distances) to identify 'candidate' species of Neotropical anurans including Pristimantis. In our study, interspecific genetic distances for the 15 species of Pristimantis range from 3\% to 22\% (mean $=15 \%$, $\mathrm{SD}=2, n=8286$ comparisons), whereas intraspecific divergences range from $0 \%$ to $11 \%$ (mean $=5 \%, \mathrm{SD}=3, n=3495$ comparisons), which implies a broad overlap of intraspecific with interspecific genetic distances (Fig. 3). Thus, if the 3\% threshold was to be applied to our case study, 34 species should be recognized (Fig. 1). We, however, reject to recognize those 34 units as 'candidate' species because arbitrary thresholds are forbidden by the evolutionary species concept (see earlier). The magnitude of differences in intraspecific genetic divergences varies strongly from lineage to lineage because of the different phenomena involved in the divergences at the population level (Whitlock 2003). And, although variation in mean intraspecific and interspecific genetic divergences may reflect the different history of species, this variation cannot be used to establish universal thresholds to identify their origins or limits. For example, most species included in our study occur above 1500 m.a.s.l. in the Andes, which may explain the higher divergence in comparison with those found among lowland species (Fouquet et al. 2007). The complex Andean orography and intense orogeny (GregoryWodzicki 2000), together with recent climatic changes (Pennington et al. 2001; Killeen et al. 2007), might have contributed to reductions in range size and effective population sizes leading to higher amount of genetic differentiation in the Andean species analysed, as evidenced for other groups of montane organisms (Knowles \& Richards 2005; Hughes \& Eastwood 2006; Weir 2006; Carstens \& Knowles 2007).

\section{The stability of species names}

The degree of stability in species names is a matter of great concern for users of species names, who see their comparative units and, hence, their predictions, changing after taxonomic reanalysis (Agapow et al. 2004; Isaac et al. 2004; Padial \& De la Riva 2006). This stability is also important for conservationists, who may sometimes experience the frustration of ignoring which entity they are conserving after taxonomic revisions. Some examples (see later) illustrate that the degree of support varies among species, and so varies the degree of stability we can expect from their names. Complete stability of species names or species lists cannot be demanded to a hypothesis-driven taxonomy (Padial \& De la Riva 2006), but taxonomists can prevent users of species names from having to confront complete uncertainty by providing some indication of the degree of stability that can be expected from recently proposed or evaluated hypotheses (Table 1).

Of the 15 nominal species evaluated with three lines of evidence, all are supported by at least one, and so none of them is rejected. Among the 15 species, nine are supported by at least two sources of evidence with different underlying assumptions and can be considered as well-supported and stable species (Table 1). But among the other six species, differences in support are evident.

On one side, the siblings $P$. fenestratus and $P$. koehleri are reciprocally monophyletic but without support, and their advertisement call parameters overlap. Also, the siblings $P$. danae and $P$. reichlei are reciprocally monophyletic but without support, and are morphologically cryptic but have differentiated advertisement calls (Fig. 1). This situation suggests that those species could have diverged recently, and species boundaries are, therefore, more difficult to interpret in absence of sufficiently large sample sizes (Funk \& Omland 2003; Shaffer \& Thomson 2007). The status of these four species is, therefore, very likely to be confirmed by adding more specimens or characters. We here consider them stable. 
Pristimantis llojsintuta and P. platydactylus, represent a different panorama. The phylogenetic analysis of the $16 \mathrm{~S}$ gene indicates that P. llojsintuta forms a monophyletic group nested within what is called now P. platydactylus (see Fig. 1); the calls differ between them, but so far we have been unable to find any morphological character to tell them apart. This could suggest that they represent a single species, the distinctive call of $P$. llojsintuta being only the result of confusion with another type of call (e.g. aggressive call). Divergent basal lineages for $P$. platydactylus also suggests that this species name probably represents a complex of morphologically cryptic species, one of them being $P$. llojsintuta. Thus, if $P$. platydactylus would be split in several species, the name $P$. llojsintuta and $P$. platydactylus would be applied to entities different from those to which they currently refer to. In short, the status of the species hypotheses $P$. llojsintuta and Bolivian P. platydactylus are pending further analyses and increasing taxon sampling. We recommend to considering these species names instable.

\section{Conclusions}

The exclusive use of single lines of evidence or the application of arbitrary thresholds to discover species does not only impair and bias our potential for discoveries, but also limits the possibility to understand evolutionary processes. Only an integrative approach combining every source of evidence provides the necessary feedback to test and discover all species. This approach further allows identifying those species that are probably representing stable comparative units, to flag species pending reassessment and to predict future taxonomic changes. Integrative taxonomists should provide users of species names with information about the degree of stability that they can expect from nominal species. Taxonomy will become thus more valuable for those users of species names that need as much stability as possible in their comparative units.

\section{Acknowledgements}

Most of JMP's field work in Bolivia was financed by a grant of the Mutis program of the MAE-AECI (Spain); his trip to visit the museums in USA was funded by an Ernst Mayr Travel Grant in Animal Systematics (Museum of Comparative Zoology, Harvard University), and his trip to visit the Natural History Museum (London) was funded by the 'European Commission's Research Infrastructure Action' via the SYNTHESYS programme (GB-TAF-299). Studies of JK were supported by grants of the German Academic Exchange Service (DAAD), the SYNTHESYS programme (ESTAF-2567), and Graduiertenförderung des Landes NordrheinWestfalen. The work of SCF has been financed by grants from Stiftelsen Sven och Lilly Lawskis (Sweden), Helge Ax:son Johnsons Stiftelse Foundation (Sweden), Sederholms' stipend (Sweden), and The Royal Swedish Academy of Science.
CV was sponsored by the Andalusian Government (Programa de Captación del Conocimiento para Andalucía, Spain). This work was partially funded by projects REN/GLO 2001-1046 and CGL2005-03156 of the Spanish Ministry of Education and Science (I. De la Riva, Principal Investigator), and by the Swedish Research Council (C. Vilà, Principal Investigator). The authors thank K. de Queiroz, M. Brazeau and K. C. Wollenberg for their constructive criticisms on a previous draft of the manuscript.

\section{References}

Agapow, P. M., Bininda-Emonds, O. R. P., Crandall, K. A., Gittleman, J. L., Mace, G. M., Marsahll, J. C. \& Purvis, A. (2004). The impact of species concept on biodiversity studies. Quarterly Review of Biology, 79, 161-179.

Agnarson, I. \& Kuntner, M. (2007). Taxonomy in a changing world: seeking solutions for a science in crisis. Systematic Biology, 56, 531-539.

Akaike, H. (1974). A new look at the statistical model identification. IEEE Transactions on Automatic Control, 19, 716-723.

Alfaro, M. E., Zoller, S. \& Lutzoni, F. (2003). Bayes or bootstrap? A simulation study comparing the performance of Bayesian Markov chain Monte Carlo sampling and bootstrapping in assessing phylogenetic confidence. Molecular Biology and Evolution, 20, 255266.

Avise, J. C. (2000). Phylogeography. The History and Formation of Species. Cambridge: Harvard University Press.

Avise, J. C. \& Deette, W. (1999). Species realities and numbers in sexual vertebrates: perspectives from an asexually transmitted genome. Proceedings of the National Academy of Sciences USA, 96, 922-995.

Bickford, D., Lohman, D. J., Navjot, S. S., Ng, P. K. L., Meier, R., Winker, K., Ingram, K. K. \& Das, I. (2007). Cryptic species as a window on diversity and conservation. Trends in Ecology and Evolution, 22, 148-155.

Carstens, B. C. \& Knowles, L. L. (2007). Shifting distributions and speciation: species divergence during rapid climate change. Molecular Ecology, 16, 619-627.

Cunha, R. L., Castilho, R., Rüber, L. \& Zardoya, R. (2005). Patterns of cladogenesis in the venomous marine gastropod genus Conus from the Cape Verde Islands. Systematic Biology, 54, 634-650.

Darst, C. R. \& Cannatella, D. C. (2004). Novel relationships among hyloid frogs inferred from $12 \mathrm{~S}$ and $16 \mathrm{~S}$ mitochondrial DNA sequences. Molecular Phylogenetics and Evolution, 31, 462-475.

Dayrat, B. (2005). Toward integrative taxonomy. Biological Journal of the Linnean Society, 85, 407-415.

de Queiroz, K. (2005a). Ernst Mayr and the modern concept of species. Proceedings of the National Academy of Sciences, USA, 102, 6600-6607.

de Queiroz, K. (2005b). A unified concept of species and its consequences for the future of taxonomy. Proceedings of the California Academy of Sciences, 56(Suppl. 1), 196-215.

de Queiroz, K. (2005c). Different species problems and their resolution. Bioessays, 27, 1263-1269.

de Queiroz, K. (2007). Species concepts and species delimitation. Systematic Biology, 56, 879-886.

Desalle, R., Egan, M. G. \& Sidall, M. (2005). The unholy trinity: taxonomy, species delimitation and DNA barcoding. Philosophical Transactions of the Royal Society of London B, 360, 1905-1916. 
Duellman, W. E. (2005). Cusco Amazónico: The Lives of Amphibians and Reptiles in an Amazonian Rainforest. Ithaca: Cornell University Press.

Erixon, P., Svennblad, B., Britton, T. \& Oxelman, B. (2003). Reliability of Bayesian posterior probabilities and bootstrap frequencies in phylogenetics. Systematic Biology, 52, 665-673.

Faith, D. P. (2004). From species to supertrees: Popperian corroboration and some current controversies in systematics. Australian Systematic Botany, 17, 1-16.

Faith, D. P. \& Trueman, J. W. H. (2001). Towards an inclusive philosophy for phylogenetic inference. Systematic Biology, 50, 331350.

Fouquet, A., Gilles, A., Vences, M., Marty, C., Blanc, M. \& Gemmell, N. J. (2007). Underestimation of species richness in Neotropical frogs revealed by mtDNA analyses. PLoS One, 2, e1109.

Frost, D. R. (2007). Amphibian Species of the World: an Online Reference. Available via http://research.amnh.org/herpetology/amphibia/ index.php.

Frost, D. R., Grant, T., Faivovich, J., Bain, R. H., Haas, A., Haddad, C. F. B., de Sá, R. O., Channing, A., Wilkinson, M., Donnellan, S. C., Raxworthy, C. J., Campbell, J. A., Blotto, B. L., Moler, P., Drewes, R. C., Nussbaum, R. A., Lynch, J. D., Green, D. M. \& Wheeler, W. C. (2006). The amphibian tree of life. Bulletin of the American Museum of Natural History, 297, 1-370.

Frost, D. R. \& Kluge, A. G. (1994). A consideration of epistemology in systematic biology, with special reference to species. Cladistics, 10, 259-294.

Funk, D. J. \& Omland, K. E. (2003). Species-level paraphyly and polyphyly: frequency, causes, and consequences, with insights from animal mitochondrial DNA. Annual Reviews in Ecology, Evolution and Systematics, 34, 397-423.

Gene Codes Corporation (2000). Sequencher, Version 4.1. Ann Arbor, Michigan: Gene Codes Corporation.

Gerhardt, H. C. (1994). The evolution of vocalization in frogs and toads. Annual Reviews in Ecology and Systematics, 25, 293-324.

Gregory-Wodzicki, K. M. (2000). Uplift history of the Central and Northern Andes: a review. GSA Bulletin, 112, 1091-1105.

Heckman, K. L., Rasoazanabary, E., Machlin, E., Godfrey, L. R. \& Yoder, A. (2006). Incongruence between genetic and morphological diversity in Microcebus griseorufus of Beza Mahafaly. BMC Evolutionary Biology, 6, 98.

Hedges, S. B., Duellman, W. E. \& Heinicke, M. P. (2008). New World direct-developing frogs (Anura: Terrarana): Molecular phylogeny, classification, biogeography, and conservation. Zootaxa, 1737, 1-182.

Hewitt, G. M. (2004). The structure of biodiversity-insights from molecular phylogeography. Frontiers in Zoology, 1, 1-16.

Hey, J., Waples, R. S., Arnold, M. L., Butlin, R. K. \& Harrison, R. G. (2003). Understanding and confronting species uncertainty in biology and conservation. Trends in Ecology and Evolution, 18, 597-603.

Hillis, D. M., Moritz, C. \& Mable, B. K. (1996). Molecular Systematics. Suderland: Sinauer.

Huelsenbeck, J. P. \& Ronquist, F. (2001). MRBAYEs: Bayesian inferences of phylogenetic trees. Bioinformatics, 8, 754-755.

Hughes, C. \& Eastwood, R. (2006). Island radiation on a continental scale: exceptional rates of plant diversification after uplift of the Andes. Proceedings of the National Academy of Sciences, USA, 103, 10334-10339.

Isaac, N. J., Mallet, J. \& Mace, G. M. (2004). Taxonomic inflation: its influence on macroecology and conservation. Trends in Ecology and Evolution, 19, 464-469.

Jansen, M. \& Köhler, J. (2007). The advertisement call of Eleutherodactylus fraudator (Anura: Brachycephalidae) from Bolivia. South American Journal of Herpetology, 2, 198-200.

Katoh, K., Kuma, K., Toh, H. \& Miyata, T. (2005). maffT: a novel method for rapid multiple sequence alignment based on fast Fourier transform. Nucleic Acids Research, 30, 3059-3066.

Killeen, T. J., Douglas, M., Consiglio, T., Jørgense, P. M. \& Mejía, J. (2007). Dry spots and wet spots in the Andean hotspot. Journal of Biogeography, Special issue, 1-17.

Knowles, L. L. \& Carstens, B. C. (2007). Delimiting species without monophyletic gene trees. Systematic Biology, 56, 887-895.

Knowles, L. L. \& Richards, C. R. (2005). Importance of genetic drift during Pleistocene divergence as revealed by analyses of genomic variation. Molecular Ecology, 14, 4023-4032.

Köhler, J. (2000a). Amphibian diversity in Bolivia: a study with special reference to montane forest regions. Bonner Zoologische Monographien, 48, 1-243.

Köhler, J. (2000b). New species of Eleutherodactylus (Anura: Leptodactylidae) from cloud forest of Bolivia. Copeia, 2000, 516-520.

Köhler, J. \& Lötters, S. (1999). New species of the Eleutherodactylus unistrigatus group (Amphibia: Anura: Leptodactylidae) from montane rain forest of Bolivia. Copeia, 1999, 422-427.

Köhler, J., Vieites, D. R., Bonett, R. M., Hita-Garcia, F., Glaw, F., Steinke, D. \& Vences, M. (2005). New amphibians and global conservation: a boost in species discoveries in a highly endangered vertebrate group. Bioscience, 55, 693-696.

Lougheed, S. C., Austin, J. D., Bogart, J. P., Boag, P. T. \& Chek, A. A. (2006). Multi-character perspectives on the evolution of intraspecific differentiation in a Neotropical hylid frog. BMC Evolutionary Biology, 6, 23.

Lynch, J. D. \& Duellman, W. E. (1997). Frogs of the genus Eleutherodactylus (Leptodactylidae) in western Ecuador: systematics, ecology, and biogeography. University of Kansas Natural History Museum Special Publications, 23, 1-236.

Márquez, R., De la Riva, I. \& Bosch, J. (1995). Advertisement calls of Bolivian Leptodactylidae (Amphibia, Anura). Journal of Zoology London, 237, 313-336.

Mayden, R. L. (1997). A hierarchy of species concepts: the denouement in the saga of the species problem. In M. F. Claridge, H. A. Dawah \& M. R. Wilson (Eds) Species: The Units of Biodiversity (pp. 381-424). London: Chapman \& Hall Ltd.

Mayden, R. L. (2002). On biological species, species concepts and individuation in the natural world. Fish and Fisheries, 3, 171-196.

Meiri, S. \& Mace, G. M. (2007). New taxonomy and the origin of species. PLoS Biology, 5, e194.

Orr, M. R. \& Smith, T. B. (1998). Ecology and speciation. Trends in Ecology and Evolution, 12, 502-506.

Padial, J. M. \& De la Riva, I. (2006). Taxonomic inflation and the stability of species lists: the perils of ostrich's behavior. Systematic Biology, 55, 859-867.

Padial, J. M. \& De la Riva, I. (2009). Integrative taxonomy reveals cryptic Amazonian species of Pristimantis (Anura). Zoological Journal of the Linnean Society, 155, 97-122.

Padial, J. M., Gonzales, L., Reichle, S., Aguayo, R. \& De la Riva, I. (2004). First records of five species of the genus Eleutherodactylus Duméril and Bibron, 1841 (Anura: Leptodactylidae) for Bolivia. Graellsia, 60, 167-174. 
Padial, J. M., Castroviejo-Fisher, S., Köhler, J., Domic, E. \& De la Riva, I. (2007). Systematics of the Eleutherodactylus fraudator species group (Anura: Brachycephalidae). Herpetological Monographs, 21, 214-241.

Padial, J. M., Chaparro, J. C. \& De la Riva, I. (2008a). Systematics of Oreobates and the Eleutherodactylus discoidalis species Group (Amphibia, Anura) based on two mtDNA genes and external morphology. Zoological Journal of the Linnean Society, 152, 737773.

Padial, J. M., Köhler, J., Muñoz, A. \& De la Riva, I. (2008b). Assessing the taxonomic status of tropical frogs through bioacoustics: geographical variation in the advertisement call in the Eleutherodactylus discoidalis species group (Anura: Brachycephalidae). Zoological Journal of the Linnean Society, 152, 353-365.

Page, T. J., Choy, S. C. \& Hughes, J. (2005). The taxonomic feedback loop: symbiosis of morphology and molecules. Biology Letters, 1 , 139-142.

Pennington, R. T., Prado, D. E. \& Pendry, C. A. (2001). Neotropical seasonally dry forest and Quaternary vegetation changes. Journal of Biogeography, 27, 261-273.

Pfennig, K. S. (2007). Facultative mate choice drives adaptive hybridization. Science, 318, 965-967.

Posada, D. \& Crandall, K. A. (1998). Modeltest: testing the model of DNA substitution. Bioinformatics, 14, 817-818.

Rannala, B. \& Yang, Z. (1996). Probability distribution of molecular evolutionary trees: a new method of phylogenetic inference. Journal of Molecular Evolution, 43, 304-311.

Rieseberg, L. H., Wood, T. E. \& Baack, E. J. (2006). The nature of plant species. Nature, 440, 524-527.

Rodríguez, L. O. (1994). A new species of the Eleutherodactylus conspicillatus group (Leptodactylidae) from Peru, with comments on its call. Alytes, 12, 49-63.

Ryan, M. J. (1988). Constraints and patterns in the evolution of anuran acoustic communication. In B. Fritzsch, M. Ryan, M. Wilczynski, W. Walkowiak \& T. Hetherington (Eds) The Evolution of the Amphibian Auditory System (pp. 637-677). New York: Wiley.

Ryan, M. J. \& Kime, N. M. (2003). Selection on long distance acoustic signals. In A. Simmons, R. Fay \& A. Popper (Eds) Acoustic Communication (pp. 225-274). Berlin: Springer Verlag.

Sambrook, J., Fritsch, E. F. \& Maniatis, T. (1989). Molecular Cloning: a Laboratory Manual. New York: Cold Spring Harbor Laboratory Press.

Shaffer, H. B. \& Thomson, R. C. (2007). Delimiting species in recent radiations. Systematic Biology, 56, 896-906.

Simpson, G. G. (1951). The species concept. Evolution, 5, 285298.

Sites, J. W. \& Marshall, J. C. (2004). Operational criteria for delimiting species. Annual Reviews in Ecology, Evolution and Systematics, 35, 199-227.

Smith, T. B., Calsbeek, R., Wayne, R. K., Holder, K. H., Pires, D. \& Bardeleben, C. (2005). Testing alternative mechanisms of evolutionary divergence in an African rain forest passerine bird. Journal of Evolutionary Biology, 18, 257-268.

Sturmbauer, C. \& Meyer, A. (1992). Genetic divergence, speciation and morphological stasis in a lineage of African cichlid fishes. Nature, 358, 578-581.

Swofford, D. L. (1998). PAUP*. Phylogenetic Analysis Using Parsimony* and Other Methods, Version 4b10. [Computer software and manual]. Sunderland MA: Sinauer Associate.
Templeton, A. R. (2001). Using phylogeographic analyses of gene trees to test species status and processes. Molecular Ecology, 10, 779-791.

Valdecasas, A. G., Williams, D. \& Wheeler, Q. D. (2008). Integrative taxonomy' then and now: a response to Dayrat (2005). Biological Journal of the Linnean Society, 93, 211-216.

Vences, M. \& Wake, D. (2007). Speciation, species boundaries and phylogeography of amphibians. In H. Heatwole (Ed.) Amphibian Biology, Vol. 7. (pp. 2613-2671) Chipping Norton: Surrey Beatty \& Sons.

Vences, M., Thomas, M., Bonett, R. \& Vieites, D. (2005). Deciphering amphibian diversity through DNA barcoding: chances and challenges. Philosophical Transactions of the Royal Society of London B, 360, 1859-1868.

Weir, J. T. (2006). Divergent timing and patterns of species accumulation in lowland and highland neotropical birds. Evolution, 60, 842-855.

Wheeler, Q. (2005). Losing the plot: DNA 'barcodes' and taxonomy. Cladistics, 2, 405-407.

Wheeler, Q. D. (2007). Invertebrate systematics or spineless taxonomy? Zootaxa, 1668, 10-18.

Whitlock, M. C. (2003). Fixation probability and time in subdivided populations. Genetics, 164, 767-769.

Wiens, J. J. (2007). Species delimitation: new approaches for discovering diversity. Systematic Biology, 56, 875-878.

Wiens, J. J. \& Penkrot, T. L. (2002). Delimiting species based on DNA and morphological variation and discordant species limits in spiny lizards (Sceloporus). Systematic Biology, 51, 69-91.

Wiens, J. J. \& Servedio, M. R. (2000). Species delimitation in systematics: inferring diagnostic differences between species. Proceedings of the Royal Society of London B, 267, 631-636.

Wiley, E. O. (1978). The evolutionary species concept reconsidered. Systematic Zoology, 27, 17-26.

Wiley, E. O. (1981). Phylogenetics. The Theory and Practice of Phylogenetic Systematics. New York: John Wiley \& Sons.

Yang, Z. \& Rannala, B. (1997). Bayesian phylogenetic inference using DNA sequences: a Markov Chain Monte Carlo method. Molecular Biology and Evolution, 14, 717-724.

\section{Appendix 1}

Voucher specimens and locality data for 26 species of Pristimantis from Bolivia and southern Peru examined for 10 morphological characters. Museum abbreviations: AMNH A: Amphibian collection of the American Museum of Natural History (New York, USA); BM: The Natural History Museum (London, UK); CBF: Colección Boliviana de Fauna (La Paz, Bolivia); CBG: Centro de Biodiversidad y Genética (Cochabamba, Bolivia); KU: Natural History Museum and Biodiversity Research Centre of the University of Kansas (Lawrence, USA); MCZ: Museum of Comparative Zoology (Cambridge, USA); MNCN: Museo Nacional de Ciencias Naturales (Madrid, Spain); MNK-A: Amphibian Collection, Museo de Historia Natural Noel Kempff Mercado (Santa Cruz de la Sierra, Bolivia); MHNC: Museo de Historia Natural, Universidad Nacional de San Antonio Abad del Cusco (Cusco, Peru); MHNSM: Museo de Historial Natural 
de la Universidad Mayor de San Marcos (Lima, Peru); NMW: Naturhistorisches Museum Wien (Vienna, Austria); MZUP: Museu de Zoologia da Universidade de São Paulo (São Paulo, Brazil); NMP: National Museum Prague (Prague, Czech Republic); USNM: National Museum of Natural History (Washington DC, USA); ZFMK: Zoologisches Forschunginstitut und Museum Alexander König (Bonn, Germany).

P. altamazonicus (11 specimens): Upper Amazon Basin, MCZ 2038 (holotype); BOLIVIA: La Paz: Candelaria, CBF 5311; Pando: Curichón, Reserva Nacional de Vida Silvestre Amazónica Manuripi-Heath, MNK-A 3878; Luz de América, MNK-A, 6879; Reserva Nacional de Vida Silvestre Amazónica Manuripi-Heath, MNK-A 3637; Federico Román, MNKA 6880; ECUADOR: Napo: 6.5 km ESE Puerto Misahualli, MCZ 118822-6.

P. ashkapara (two specimens). BOLIVIA: Department Cochabamba: Old road from Paractito via el Palmar to Cochabamba, 2100 m.a.s.l., CBF 3344 (holotype), ZFMK 70318 (paratopotype).

P. bisignatus (11 specimens). BOLIVIA: Department La Paz: Chaco, 2200 m.a.s.l., NMW 16502 (holotype); Plataforma, PN-AMNI Cotapata, 2300 m.a.s.l., CBF 4113-14, 4122, 4134, 4184; Toriri, 2658 m.a.s.l., CBF 5717-20; unknown location: Actinero, BM 1901.8.2.43.

P. buccinator (10 specimens): PERU: Madre de Dios: Blanquillo, MHNC 3098; Cocha Camu, MHNC 3132; Cocha Cashu Biological Station, Manu National Park, KU 220919 (paratype); MHNSM 3842 (holotype), 3844-7, 3865 (paratypes), USNM 299779.

P. danae (221 specimens): BOLIVIA: La Paz: Arroyo Huacataya, Madidi National Park, MNCN 43069-72, MNK-A 7190, 7199; Arroyo Huairuro, Madidi National Park, MNCN 43059-64, 43067-8, MNK-A 7181-3, 7186; Valle de Zongo, MNCN 4279, 43144; PERU: Cusco: Km 137 on Paucartambo-Atalaya road, 2200 m.a.s.l., USNM 346118; Km 150 on Paucartambo-Atalaya road, 1700 m.a.s.l., USNM 346123-34; Km 154 on Paucartambo-Atalaya road, 1500 m.a.s.l., USNM 346137; Paucartambo, 72-75 km N of, USNM 298247-55, 298257-97; Paucartambo, 68 km by road. NE of Puente Unión on río Tachila, USNM 346346-51; Puente Quitacalzón, 1180 m.a.s.l., MHNSM 17203-7, USNM 345925-7, 346119-22, 346356-9; Quebrada Morro Leguía, km 137 on Paucartambo-Atalaya road., 2200 m.a.s.l., USNM 346344-5; Río Cosñipata, 2.5 km (by road) SW of Santa Isabel, 1620 m.a.s.l., KU 138878; Río Cosñipata, 4 km (by road) SW of Santa Isabel, 1700 m.a.s.l., KU 162307 (holotype) KU 162308-57 (paratypes), MCZ 93305-10 (paratypes); Río Cosñipata, 6 km (by road) SW of Santa Isabel, 1270 m.a.s.l., KU 162358-64 (paratypes), MHNSM 13957 (paratype); Río San Pedro, 72 km by road. NE of Paucartambo, 1500 m.a.s.l., USNM 342769, 345928-54, 346352-55; Santa Isabel, km
157 on Paucartambo-Pilcopata road, 1300 m.a.s.l., MHNSM 17193-202, 17208-10, 17211-3, USNM 346135-6.

P. carvalhoi (82 specimens): PERU: Loreto: Bellavista, Yubineto, NMW 24896 (2 specimens); Requena, USNM 332963-68; USNM 537771-844.

P. croceoinguinis (29 specimens): ECUADOR: Napo: Santa Cecilia, KU 110789 (holotype); Pastaza: 1 km SW of Puyo, MCZ 134398; $10 \mathrm{~km}$ ESE of Veracruz, MCZ 9124-51.

P. fenestratus (323 specimens): BOLIVIA: Beni: Arroyo Agua Clara, MNK-A 3820; Asunción, MNK-A 4058, 4066, 4070-1; Laguna Azul, MNK-A 4007; Misiones Mosetenes, BM 98.6.9.21; Rurrenabaque, MNK-A 3784-9, 3790-1; San Luis Chico, MNK-A 4013-5, 4032; Serranía del Pilón, Antena de Entel, MNK-A 4150-5, 4175-6, 4199-200; Río Yucumo, MNCN 43149-50, 43838, 43841; Cochabamba: Altamachi, CBG 486-7; between Parajti and El Palmar, ZFMK 66965-6; between El Palmar and Paractito, ZFMK 72545-6, 72536; road to San Onofre from CochabambaVilla Tunari road, MNCN 43109, 43119; Chaquisacha, Carrasco National Park, 1500 m.a.s.l. CBG 219; Charuplaya, 1300 m.a.s.l. BM 1902.5.29.106-109; Los Guácharos (=El Palmar, 500 m.a.s.l.), CBG 301-7, 349-358, MNCN 43031, 43142; ríos Altamachi-Malpaso, CBG 439, 492-8; Santa Anita, Isiboro-Sécure National Park, CBG 744-5, 747-9; Santa Domingo, Isiboro-Sécure National Park, CBG 61315, 617; Valle de Sajta, MNK-A 3561; Villa Fátima, CBG 556-559; Villa Tunari, MNK-A 1493; La Paz: Arroyo Amahuachi, Camino Maderero Bellavista, MNK-A 3801-3; Arroyo Mikai, Camino Maderero el Chaval, MNK-A 3757, 3763-8, 3762; Boquerón, ANMI Pilón-Lajas, 1000 m.a.s.l., CBG 773; Chalalán, A.N.M.I. Madidi, MNCN 42980, 43057, 43239-40, 43242-44; Chulumani, 1700 m.a.s.l., BM 1940.4.5.59; Huachi, MCZ 10094-5; Juapi, A.N.M.I PilónLajas, CBG 681-7; La Cascada, MNCN 43037; Sadiri, Arroyo Yariapo, Madidi National Park, MNCN 42982, 42984; Serranía Beu, A.N.M.I Pilón-Lajas, CBG 901-6; San Ernesto, Mapiri 500 m, BM 1901.8.2.53; San Ignacio, MNKA 4083-7, 4151; Serranía de Bella Vista, MNCN 43146; Serranía de Chepite, 3730, 3735, 3736, 3746-8; Valle de Zongo, ZFMK 72524-5; Pando: Arroyo Capinduro, Santa Rosa del Abuná, MNK-A 6881; Arroyo Tulapa, Reserva Nacional de Vida Silvestre Manuripi, MNK-A 5177; Barraca Hiroshima, Reserva Nacional de Vida Silvestre Manuripi, MNK-A 5193-6; Barraca San Carlos, Madre de Dios, MNKA 4562; Campamento Malecom, Reserva Nacional de Vida Silvestre Manuripi, MNK-A 6052, 6059; Campamento Serna-Humaita, Reserva Nacional de Vida Silvestre Manuripi, MNK-A 4404; Chivé, Reserva Nacional de Vida Silvestre Manuripi, MNK-A 5011-2, 6124-7, 6883, 6888-9, MNCN 43153-4; Cobija, ZFMK 66795-99; Curichón, Reserva Nacional de Vida Silvestre Manuripi, MNK-A 6894; Florida, Reserva Nacional de Vida Silvestre Manuripi, 
MNK-A 5084, 5091-4, 5115; Gran Progreso, Reserva Nacional de Vida Silvestre Manuripi, MNK-A 5070; Hiroschima, MNCN 43152; Laguna Bay, Reserva Nacional de Vida Silvestre Manuripi, MNK-A 4945, 6114-7; Mukden, 4620-4628; Nueva España, Reserva Nacional de Vida Silvestre Manuripi, MNK-A 3664, 3668-9, 3673-4; Puerto Loreto, río Madre de Dios, MNK-A 6882, 6884-7; Reserva Tahuamanu, MNKA-A 4629; Río Negro, Federico Román, MNK-A 6909; San Antonio, Reserva Nacional de Vida Silvestre Manuripi, MNK-A 6890, 6892-3, 6895; Santa Cruz: Buenavista, 500 m.a.s.l. AMNH 34004, 34008, 34010; Lago Caimán, Parque Nacional Noel Kempff Mercado, MNK-A 2810, 2815-7, 2820. 2822-7, 2829; Mataracú, MNK-A 3928, 3930-49, 3951, 3953, 3955-67, 3969-70; Quebrada Tesoro, Parque Nacional Noel Kempff Mercado, MNK-A 169; BRAZIL: Amazonas: Borba, NMW 19940:2 (paralectotype); ca. $2 \mathrm{~km} \mathrm{~N}$ of km 70 on Manaos-Itacoatiara road, AMNH 139278; Manaos, AMNH 71437; Matto Grosso: Tumbador, between Mantino and Rosario rivers, 450 m.a.s.l., BM 1928.1.12.10-12; Rondônia: río Mamoré, NMW 1940:1 (lectotype); PERU: Cusco: Quincemil, $40 \mathrm{~km} \mathrm{SE} \mathrm{of,} 800$ m.a.s.l., KU 175097-9, 196462-3; 6,2 km of Puente Fortaleza to Quince Mil, MNCN 43250; Madre de Dios: Cuzco Amazónico, 15 km E of Pto. Maldonado KU 194906-8, 209174-5, 205109-16, 205118-19, 205121-31, 215463-73; Juliaca, río Heath, Santuario Nacional Pampas del Heath, MCZ 136344; Tambopata Wildlife Reserve, junction río La Torre and río Tambopata, BM 1987.609; Puno: between Santa Rosa and San Juán del Oro, MNCN 43245; Juliaca (in error), AMNH 6119-20; La Unión, río Huacamayo, Carabaya, BM 1907.5.7.14-16, 1911.12.20.40-1; Marcapata Valley BM 1902.5.29.196; Ucayali: Balta, río Curanja, 200 m.a.s.l., KU 175095; Coengua River, upper Uyacali river AMNH 42067.

P. fraudator (77 specimens). BOLIVIA: Department Cochabamba: Camino antiguo a Aguirre, CBG 53-4; Ceja de Monte antes de Corani hacia Cochabamba, MNCN 43344; Monte Punkhu, CBG 059; Río Chua Khocha, MNKA 635-6; Sehuencas 2000-2500 m.a.s.l., CBG 001-5, ZFMK 60244-54; $3.8 \mathrm{~km}$ on road from El Empalme to Khara Huasi, tributary of río Hualla Mayu, 2275 m.a.s.l., UTA 45602; 8.6 km N of El Empalme, road to Cochabamba, 2825 m.a.s.l., UTA 45603; $73.5 \mathrm{~km}$ from Cochabamba to Villa Tunari, USNM 257847 (Holotype), USNM 257846 (paratopotype), MNCN 43107; 38 km de Comarapa en dirección a Locotal, 2250 m.a.s.l., MNCN 43339; Department Santa Cruz: Laguna Tingui, 5 km N from Comarapa, MNKA 1746; Serranía de la Siberia, CBF 4681-2, CBG 041-5, MNCN 43329-43338, 43340-43343, 43345-43358, MNKA 908-919, ZFMK 72660-62.

P. imitatrix (14 specimens): PERU: Madre de Dios: Cuzco Amazónico, 15 km E Puerto Maldonado; KU205139-41,
KU207709-14, KU215474-78; Huánuco: Río Llullapichis, 4-5 km upstream from río Pachitea, 200 m.a.s.l., KU 171892 (holotype).

P. koehleri (49 specimens). BOLIVIA: Santa Cruz: AngosturaSamaipata road 6 km of, MNK-A 6626 (holotype), MNCN 42990-1 (paratypes), MNK-A 6627 (paratypes); Espejillos MNK-A 6447, 7170, 7172, 7174, MNCN 43054; La Chonta, Amboró National Park, MNCN 42983, 42985-6, 43014, 43040; Macuñucú, Amboró National Park, ZFMK 80005-7; Mataracú, Amboró National Park, ZFMK 79991-3; Río Saguayo, Amboró National Park, MNK-A 189, 191, 224, 358, 361, 364-5, 374; Río Surutú, Amboró National Park, MNK-A 1197; Santa Cruz de la Sierra, BM 1904.10.29.83101; Santa Cruz de la Sierra-Samaipata road, 29 km from Santa Cruz, MNK-A 1000.

P. Ilojsintuta (12 specimens). BOLIVIA: Cochabamba: Sehuencas, CBF 3300-1 (holotype and paratype), MNCN 43003-6, ZFMK 60216-7, 60219, 66387-9.

P. martiae (12 specimens): ECUADOR: Napo: Hacienda Primavera, MCZ 95580, 91832; Limoncocha, MCZ 98043; Santa Cecilia, MCZ 58004; Pastaza: $1 \mathrm{~km} \mathrm{~W}$ of Puyo, KU 90315-17; 10 km ESE of Veracruz, MCZ 90342; Río Rutuno, tributary of río Bobonaza, USNM 233126-9.

P. mercedesae (12 specimens). BOLIVIA: Department Cochabamba: 'Old' Chapare road, 1300-1500 m.a.s.l., ZFMK 72571-73; 'Old’ Chapare road, 1650 m.a.s.l., ZFMK 7259799; Pampa Grande, National Park Altamachi, MHNC-AMS 196; $3.3 \mathrm{~km} \mathrm{~N}$ of Cochabamba to Villa Tunari road on road to San Onofre, at a point $97.5 \mathrm{~km}$ from Cochabamba on Cochabamba to Villa Tunary road, 1690 m.a.s.l., UNSNM 257848 (holotype); Limbo, $73.5 \mathrm{~km}$ from Cochabamba to Villa Tunari, 1950 m.a.s.l., USNM 165753 (Paratype). Department La Paz: Hornuni, PN-ANMI Cotapata, Prov. Nor Yungas, CBF 4120; road to Coroico, Serranía Bella Vista, Prov. Nor Yungas, CBF 3701. PERU: Department Cusco: Paucartambo, $68 \mathrm{~km}$ by road NE of Puente Unión on río Tachila (Bosque de las Nubes, Km 150 on Paucartambo-Atalaya road), 1700 m.a.s.l., USNM 346140.

P. ockendeni (14 specimens): PERU: Huánuco: Río Llullapichis, Panguana, 220 m.a.s.l., NMW, 28965 (6 specimens), 29035; Loreto: between Bella Vista and Yubineto, NMW 24915; Puno: La Unión, Carabaya, 2000 ft., BM 1947.2.16.8890 (types); Ucayali: Iparia, La Paz trail, MCZ 7059-61.

P. olivaceus (20 specimens): BOLIVIA: Cochabamba: between El Palmar and Paractito, CBG 3329 (holotype), 3330 (paratype), ZFMK 67132-3 (paratypes) 72533-4, 72549-50, 72553, 72568, 72578-9; 144 km from Cochabamba to Villa Tunari, USNM 146569-75; PERU: Madre de Dios: Manu, USNM 442615.

P. peruvianus (248 specimens): BRAZIL: Amazonas: Igarapé Belém, near río Solimoes, ca. $70 \mathrm{~km}$ E from Leticia, AMNH 96903-97042; ECUADOR: Morona Santiago: Ashuara 
Village on Río Macuma, 300 m.a.s.l., ca. $10 \mathrm{~km}$ above río Morona (ca. 83 km ESE Macas), AMNH 94656-78; Cusuine, AMNH 93583-655; Río Piuntza, 1830 m.a.s.l., KU 147034-38; Napo: Río Azuela, 1700 m.a.s.l., AMNH 222024, KU 143502-3; Río Salado, 1 km from río Coca, 1410 m.a.s.l., KU 165859-65; southern slope of Cordillera del Dué, above río Coca, 1150 m.a.s.l., KU 123446, 123502; 3.2 km NNE, Oritiyacu, 1910 m.a.s.l., KU 165860; 16 km NNE of Santa Rosa, 1700 m.a.s.l., KU 143498-501; Pastaza: Río Pastaza, from Canelos to Marañón, MCZ 19635, 89314, 19639; PERU: Cusco: Cordillera Vilcabamba 1680 m.a.s.l., AMNH 79812-13; Huánuco: Cordillera Azul, La Divisoria, Río Azul, AMNH 86496-7; Loreto: Teniente López, 200 m.a.s.l., KU 222030; Yagua Indian Village, headwaters of Río Loretoyacu, AMNH 96303-30; 1.5 km N Teniente López, 310-340 m.a.s.l., KU 222024-9; San Martín: Río Cainasache, $33 \mathrm{~km}$ NE Tarapoto on road to Yurimaguas, KU 209475-77; Roque, NHMG 490 (holotype); 15.4 km SW Zapateros, 950 m.a.s.l., KU 217313; 20 km NE Tarapoto on road to Yurimaguas, KU 209473-4; 48 km NE Tarapoto, KU 217312.

P. platydactylus (28 specimens): BOLIVIA: Cochabamba: Los Guácharos (=El Palmar, 500), MNCN 43029-30, 43033-4; La Paz: Serranía de Bellavista, MNCN 43147; Santa Cruz: La Siberia, MNCN 42992-43001, 43082-88; PERU: Cusco: Entre San Miguel y Marcapata, MNCN 43248; Puno: Santa Domingo de Carabaya, 6000 ft., BM 1947.2.15.91-96 (types, five specimens).

P. pluvicanorus (126 specimens). BOLIVIA: Department Cochabamba: Incachaca, 2300 m.a.s.l., ZFMK 66938; La Siberia, camino de Locotal y Carahuasi, 2050 m.a.s.l., MNCN 43285-43288; Pojo, CBF 1597; 'Old Chapare Road' between Paractito and El Palmar, 2250 m.a.s.l., ZFMK 72619-20; Río Chua Kocha, MNKA 1100 (Holotype), 11014 (paratopotypes), MNKA 627-630; road near Penstock's bridge, MNCN/ADN 6004; Sehuencas 2000-2500 m.a.s.l., CBG 91-97, 128-134, MNCN 43002, 43281-43284, 43292, 43293-43296 (paratypes); ZFMK, 60186-91 (paratypes), 60195-6 (paratypes), 60203 (paratypes), 60192-4, 60197202, 60204; 38 km de Comarapa en dirección a Locotal, 2250 m.a.s.l., MNCN 43289; Department Santa Cruz: Abra de la Cruz, NKA 6712, 6714-17; El Chapé (=La Yunga de Mairana), $15 \mathrm{~km} \mathrm{~N}$ of Mairana, MNKA 3486, 3505, 3514, 3528-9, 6623, MNCN 43035, MNCN 43273-43280, 43291, 43297 (Paratype); ZFMK 66872-5; El Corral de China Vilcar, MNKA 6991-2, 6997-7003, 7008, 7010, 7012-5, 7018, 7032, 7041; Entrando desde Mataral por San Juan del Potrero, MNCN 43290; Filo del Rasete, MNKA 6856, 6931, 6939, 6941-6, 6964-7, 6969; Río Amparo, 5 km (aprox.) above the confluence of the Río Cerro Bravo and Río Amparo, Amboró National Park, AMNH 165194; Río de las Orquídeas, 2040-2060 m.a.s.l., Amboró National Park, AMNH 165193; Serranía de la Siberia, CBF 1597, 4677-80,
MNKA 5590, ZFMK 72663-4; tree fern forest above base camp, closest town San Juan del Potrero, Amboró National Park, AMNH 165211.

P. reichlei (86 specimens). BOLIVIA: Departamento Beni: Serranía del Pilón, Antena de Entel, MNK-A 4178, 4203-7, 4181; Departamento Cochabamba: Los Guácharos 500 m.a.s.l., Carrasco National Park, MNK-A 6620 (holotype), MNCN 43012, 43024, 43028, CBG 327, 328, 329 (paratopotypes); between Paractito and El Palmar, Carrasco National Park, ZFMK 72587-9, 72564-5, 72537; between Parajti and El Palmar, Carrasco National Park, ZFMK 66973-6, 66988; Villa Tunari, ZFMK 59574; Departamento La Paz: Arroyo Pico Plancha, Madidi National Park, MNCN 43071-2, MNK-7193; Serranía de Bella Vista, MNK-A 7273; Chalalán, Area Natural de Manejo Integrado Madidi, MNK-A 7178; Departamento Pando: Bioceanica, NMP6V 72578/1-2; Florida, Reserva Nacional de Vida Silvestre Manuripi, MNCN 43151; PERU: Departamento Cusco: 5 km from San Lorenzo on the road to Quince Mil, MNCN 43249; Departamento Huánuco: Río Llullapichis, Panguana, 220 m.a.s.l., NMW 28966 (10 specimens); Departamento Madre de Dios: Cocha Cashu, Manu National Park; Cuzco Amazónico, 15 km E of Puerto Maldonado, KU 154856-57, KU 205107, KU 205120, KU 205132-4, KU 205137, KU 205142, KU 207708, KU 207716-7, KU 215481, KU 215482-8; Manu river, Manu National Park, 365 m.a.s.l., KU 154853-4, KU 1548535; Puesto Euahuipa, Río Palma Real Grande, Santuario Nacional Pampas del Heath, MCZ 136394; Pakitza, Reserve Zone, Manu National Park, ca. 57 km (airline) NW of mouth of Río Manu, on Río Manu USNM 298900-1, USNM 3426230-2, USNM 342854-55, 345174-81.

P. rhabdolaemus (26 specimens): BOLIVIA: Santa Cruz: Paredones del Amboró, Amboró National Park, MNCN 43074-80; PERU: Cusco: Buenos Aires 2400 m.a.s.l., KU 173236 (holotype of $P$. pharangobates), 173237-53 (paratypes); West side of Cordillera Vilcabamba, 2125 m.a.s.l., AMNH 82511 (paratype).

P. samaipatae (25 specimens): BOLIVIA: Santa Cruz: El Fuerte, Samaipata, ZFMK 59600 (holotype); Espejillos, MNK-A 6444, 6448; Estancia Cuevas, 101 km from Santa Cruz de la Sierra to Samaipata, MNK-A 672, ZFMK 668823; Km 6 Angostura-Samaipata road, MNCN 42987-9; Río Parabano, MNK-A 6689-91; Río Seco, 40 km W of, ZFMK 67073; Río Seco, 45 km W of, ZFMK 67071-2; Road to Bella Vista from Santa Cruz-Samaipata road, MNCN 43048-51, ZFMK 71998-9; Samaipata, ZFMK 83086; Serranía del Toce, Los Vidrios, MNK-A 3497; 7 km from Samaipata to Santa Cruz de la Sierra, MNK-A 1744-5

P. skydmainos (38 specimens): BOLIVIA: Pando: Río Negro, MNKA 6911-12; BRAZIL: Acre: Humaitá, at km 29 on río Blanco to Pto. Acre road, AMNH 139279-81; PERU: Amazonas: Alva, btw. Chachapoyas and Bagua Grande, 1000 
m.a.s.l., MCZ 89074-80 (type series of P. karcharias); Huánuco: Río Llullapichis, Panguana, 220 m.a.s.l., KU 218292 (paratype); Madre de Dios: Cocha Cashu Biological Station, Manu National Park, AMNH 134165-6 (paratypes), 139010-6 (paratypes), MCZ 88304 (holotype), 88305-9 (paratypes), MHNSM 9090-1 (paratypes); Colpa de Guacamayos, río Tambopata, 700 m.a.s.l., USNM 324334-6 (paratypes); La Colpa, río Tambopata, MHNSM 9081 (paratype); vicinity of Cocha Cashu, approx. $70 \mathrm{~km}$ (airline) NW of mouth of río Manu, on río Manu, USNM 298914-5 (paratypes); Pasco: Bosque Castilla, Oxapampa, MHNSM 11176-7; Puno: ridges above mouths of Candamo and Guacamavo Rivers. MHNSM 9080 (paratype).

P. toftae (32 specimens): BOLIVIA: Cochabamba: Los Guácharos (=El Palmar, 500 m.a.s.l.), MNCN 43025; PERU: Huánurn. Rín I.lullanirhic $45 \mathrm{~km}$ unstream from Rín

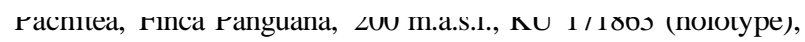
KU 1Ь48U6-19 (paratypes), KU 1\%18Ь2-62 (paratypes), KU 171864-66 (paratypes); Cusco: San Miguel, Marcapata valley, MNCN 43246-7.

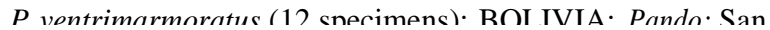

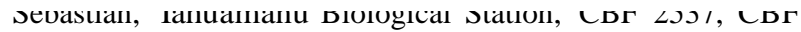
2539; ECUADUR: Pastaza: Mera, 1140 m.a.s.I., KU 119805-6, 119809; 1 km E of Mera, Río Alpayacu, 1100 m.a.s.l., KU 119807-8; 8 km NW of Mera, Abitagua, 1300 $\mathrm{m}$ a cl KIT 119811. PFRIT. Iunín. Chanchamavn $260 \mathrm{ft}$ Divi 104/.L.10./J-0 (Lypes, ivur speciniens).

P. zimmermanae (18 specimens): BULIVIA: Pando: San Sebastián, Tahuamanu Biological Station CBF 2537, 2539; BRAZIL: Amazonas: Inpa, Manaos, MZUSP 64539 (holotype), MZUSP 64535-38, 64540-1 (paratypes), MZUSP 61550-5, USNM 304278-9 (paratypes), NMW 33708.
Appendix 2 External morphological character states for 26 species of Pristimantis from Bolivia and Southern Peru.

\begin{tabular}{|c|c|c|c|c|c|c|c|c|c|c|}
\hline \multirow[b]{2}{*}{ Pristimantis } & \multicolumn{10}{|c|}{ Character states } \\
\hline & I & II & III & IV & V & VI & VII & VIII & IX & $x$ \\
\hline \multicolumn{11}{|l|}{ P. conspicillatus group } \\
\hline P. buccinator & 0 & 0 & 1 & 1 & 2 & 1 & 0 & 1 & 0 & 1 \\
\hline P. fenestratus & 1 & 1 & 1 & 0 & 0 & 1 & 1 & 1 & 0 & 0 \\
\hline P. koehleri & 1 & 1 & 1 & 0 & 0 & 1 & 0 & 1 & 0 & 0 \\
\hline P. peruvianus & 1 & 0 & 1 & 0 & 2 & 1 & 1 & 1 & 0 & 1 \\
\hline P. samaipatae & 1 & 0 & 1 & 0 & 0 & 1 & 0 & 1 & 0 & 0 \\
\hline P. skydmainos & 0 & 1 & 1 & 1 & 2 & 1 & 1 & 1 & 0 & 1 \\
\hline \multicolumn{11}{|l|}{ r. unistrigatus group } \\
\hline P. altamazonicus & 2 & 2 & 2 & 0 & 0 & 0 & 0 & 1 & 1 & 0 \\
\hline P. danae & 2 & 2 & 1 & 0 & 0 & 1 & 0 & 1 & 0 & 1 \\
\hline P. carvalhoi & 2 & 2 & 2 & 0 & 0 & 0 & 0 & 0 & 1 & 0 \\
\hline P. croceoinguinis & 2 & 2 & 2 & 0 & 0 & 0 & 0 & 0 & 1 & 0 \\
\hline P. imitatrix & 2 & 2 & 2 & 0 & 0 & 0 & 0 & 1 & 1 & 0 \\
\hline P. Ilojsintuta & 2 & 2 & 2 & 0 & 0 & 1 & 0 & 0 & 2 & 0 \\
\hline P. martiae & 2 & 2 & 2 & 0 & 0 & 0 & 0 & 0 & 0 & 0 \\
\hline P. ockendeni & 2 & 2 & 2 & 0 & 0 & 0 & 0 & 0 & 0 & 0 \\
\hline P. olivaceus & 2 & 2 & 1 & 0 & 0 & 1 & 0 & 0 & 0 & 0 \\
\hline P. platydactylus & 2 & 2 & 2 & 0 & 0 & 1 & 0 & 0 & 2 & 0 \\
\hline P. reichlei & 2 & 2 & 1 & 0 & 0 & 1 & 0 & 1 & 0 & 1 \\
\hline P. rhabdolaemus & 2 & 2 & 1 & 1 & 2 & 1 & 0 & 1 & 0 & 0 \\
\hline P. toftae & 2 & 2 & 1 & 0 & 2 & 1 & 0 & 1 & 1 & 0 \\
\hline P. ventrimarmoratus & 2 & 2 & 2 & 0 & 0 & 0 & 0 & 1 & 1 & 0 \\
\hline P. zimmermanae & 2 & 2 & 2 & 0 & 0 & 1 & 0 & 0 & 0 & 0 \\
\hline \multicolumn{11}{|l|}{ Subgenus Yunganastes } \\
\hline P. ashkapara & 0 & 0 & 0 & 1 & 2 & 1 & 0 & 0 & 0 & 0 \\
\hline P. bisignatus & 0 & 1 & 1 & 0 & 0 & 1 & 0 & 0 & 0 & 1 \\
\hline P. fraudator & 0 & 1 & 0 & 0 & 2 & 1 & 0 & 0 & 0 & 0 \\
\hline P. mercedesae & 1 & 1 & 1 & 1 & 1 & 1 & 1 & 1 & 0 & 0 \\
\hline P. pluvicanorus & 0 & 0 & 0 & 1 & 2 & 1 & 0 & 0 & 0 & 0 \\
\hline
\end{tabular}

Characters and states: (I) Relative length of first and second fingers: (0) Finger I $\geq$ Finger II, (1) Finger I > Finger II, (2) Finger I < Finger II. (II) Belly skin texture: (0) smooth, (1) granular, (2) aerolate. (III) Dorsal skin texture: (0) smooth, (1) shagreen, (2) warty. (IV) Midd-dorsal tubercles or folds: (0) absent, (1) present, (2) polymorphic. (V) Dorsolateral folds: (0) absent, (1) irregular, (2) continuous. (VI) Tympanic membrane: (0) hidden, (1) visible. (VII) Toe webbing: (0) absent, (1) present. (VIII) Tarsal fold: (0) absent, (2) present. (IX) Bright coloured (yellow, orange or red) spots on belly and flanks: (0) absent, (1) present, (2) polymorphic. (X) Conspicuous spots on dark background on hidden posterior surfaces of thighs: (0) absent, (1) present. 
Appendix 3 Localities, voucher information, GenBank accession numbers and source publication for DNA sequences of a fragment of the mitochondrial 16S rRNA gene for 15 species of Pristimantis from Bolivia and southern Peru and three outgroup species of the genus Oreobates.

\begin{tabular}{|c|c|c|c|c|c|}
\hline Species & Locality & Voucher & MNCN-DNA & GenBank & Source \\
\hline \multicolumn{6}{|l|}{ Pristimantis } \\
\hline P. ashkapara & $\begin{array}{l}\text { Bolivia: Cochabamba: Old Chapare road, } \\
\text { Carrasco National Park. }\end{array}$ & ZFMK 70318 & 7312 & EU192233 & Padial et al. (2007) \\
\hline P. bisignatus & Bolivia: La Paz: Toriri & CBF 5718-9 & $6332-2$ & EU192234-5 & Padial et al. (2007) \\
\hline P. buccinator & Peru: Cusco: Blanquillo & MHNC 4887 & 9504 & EU712630 & This study \\
\hline P. buccinator & Peru: Cusco: Cocha Camungo & MHNC 4921 & 9506 & EU712631 & This study \\
\hline P. danae & $\begin{array}{l}\text { Bolivia: La Paz: Arroyo Huacataya, track } \\
\text { btw. San José and Apolo, Madidi National } \\
\text { Park }\end{array}$ & MNCN 43069, MNK-A 7190 & 6005,6040 & EU192263-4 & Padial \& De la Riva (2009) \\
\hline P. danae & $\begin{array}{l}\text { Bolivia: La Paz: Huairuro, track btw. San } \\
\text { José and Apolo, Madidi National Park }\end{array}$ & MNK-A 7182, MNCN 43062 & 5798,5837 & EU192261-2 & Padial \& De la Riva (2009) \\
\hline P. danae & $\begin{array}{l}\text { Bolivia: La Paz: Santa Cruz de Valle Ameno, } \\
\text { Madidi National Park }\end{array}$ & IDIR 4001 & 547 & EU192260 & Padial \& De la Riva (2009) \\
\hline P. danae & Bolivia: La Paz: Serranía Bella Vista & MNK-A 7273 & 6258 & EU192265 & Padial \& De la Riva (2009) \\
\hline P. danae & $\begin{array}{l}\text { Peru: Cusco: Unión, Valle de Kosñipata, } \\
\text { Manu National Park }\end{array}$ & $\begin{array}{l}\text { IDLR 4815, MNCN 44232-4, IDIR } \\
4822,4824-5\end{array}$ & $20677,20682-7$ & EU192266-72 & Padial \& De la Riva (2009) \\
\hline P. fenestratus & $\begin{array}{l}\text { Bolivia: Cochabamba: Los Guácharos, } \\
\text { Carrasco National Park }\end{array}$ & $\begin{array}{l}\text { MNCN 43031, MNK-A 6631, } \\
6633\end{array}$ & $4108,4088,4109$ & EU192275-6, 192256 & $\begin{array}{l}\text { Padial et al. (2007), Padial } \\
\text { \& De la Riva (2009) }\end{array}$ \\
\hline P. fenestratus & $\begin{array}{l}\text { Bolivia: La Paz: Chalalán, Madidi National } \\
\text { Park }\end{array}$ & MNK-A 6629 & 3947 & EU192273 & Padial \& De la Riva (2009) \\
\hline P. fenestratus & $\begin{array}{l}\text { Bolivia: La Paz: Road from Charazani to } \\
\text { Apolo, Yungas btw. rio Ñecos and rio Yuyo }\end{array}$ & IDIR 3482 & 544 & EU712632 & Padial \& De la Riva (2009) \\
\hline P. fenestratus & $\begin{array}{l}\text { Bolivia: La Paz: Sadiri, Arroyo Yariapo, } \\
\text { Madidi National Park }\end{array}$ & MNK-A 6630 & 3981 & EU192274 & Padial \& De la Riva (2009) \\
\hline P. fenestratus & Peru: Madre de Dios: Cocha Camungo & MHNC 3130, 4919 & 9496,9505 & EU192277, 712633 & Padial \& De la Riva (2009) \\
\hline P. fraudator & $\begin{array}{l}\text { Bolivia: Cochabamba } 73.5 \mathrm{~km} \text { from } \\
\text { Cochabamba to Villa Tunari }\end{array}$ & MNCN 43107 & 5984 & EU192248 & Padial et al. (2007) \\
\hline P. koehleri & $\begin{array}{l}\text { Bolivia: Santa Cruz: Km } 6 \text { Angostura- } \\
\text { Samaipata road }\end{array}$ & MNCN 42990, MNK-A 6627 & 3903,3905 & EU192278-9 & Padial \& De la Riva (2009) \\
\hline P. koehleri & $\begin{array}{l}\text { Bolivia: Santa Cruz: La Chonta, Amboró } \\
\text { National Park }\end{array}$ & MNCN 42983, 42986, 43013 & $4001,4016,4003$ & EU192280-2 & Padial \& De la Riva (2009) \\
\hline P. llojsintuta & $\begin{array}{l}\text { Bolivia: Cochabamba: Old Chapare road, } \\
\text { Carrasco National Park }\end{array}$ & ZFMK 66387, 72610 & 7314,7317 & EU712641, 712642 & This study \\
\hline P. llojsintuta & $\begin{array}{l}\text { Bolivia: Santa Cruz: La Yunga de Mairana, } \\
\text { Amboró National Park }\end{array}$ & $\begin{array}{l}\text { MNCN 43014, 43016, MNK-A } \\
6600-1,6608\end{array}$ & $\begin{array}{l}4121,5823,5839,5865 \\
5990\end{array}$ & $\begin{array}{l}\text { EU712634, 712636-7, } \\
71263,712640\end{array}$ & This study \\
\hline P. llojsintuta & $\begin{array}{l}\text { Bolivia: Santa Cruz: Paredones del } \\
\text { Amboró, Amboró National Park }\end{array}$ & MNCN 43081, MNK-A 7210, & 5805,5874 & EU712635, 712639 & This study \\
\hline P. mercedesae & $\begin{array}{l}\text { Bolivia: Cochabamba: Old Chapare road, } \\
\text { Carrasco National Park }\end{array}$ & ZFMK 72571-3, 72597-8 & $7318-22$ & EU192249-53 & Padial et al. (2007) \\
\hline P. platydactylus & $\begin{array}{l}\text { Bolivia: Cochabamba: Los Guácharos, } \\
\text { Carrasco National Park }\end{array}$ & $\begin{array}{l}\text { MNCN 43020-1, 43026, 43030, } \\
43033-4, \text { MNK-A 6603-7 }\end{array}$ & $\begin{array}{l}4080-1,4094-5,4103 \\
4105,4113-17\end{array}$ & EU712657-67 & This study \\
\hline P. platydactylus & $\begin{array}{l}\text { Bolivia: Cochabamba: Camino a San } \\
\text { Onofre, Carrasco National Park }\end{array}$ & $\begin{array}{l}\text { MNCN 43120, 43122, MNCN- } \\
\text { DNA 5831, 6132, MNK-A 7243- } \\
4\end{array}$ & $\begin{array}{l}5792,5819,5831,5981 \\
6104,6132\end{array}$ & $\begin{array}{l}\text { EU712672, 712680, } \\
712682,712692,712709- \\
10\end{array}$ & This study \\
\hline P. platydactylus & $\begin{array}{l}\text { Bolivia: Cochabamba: El Cañadon, } \\
\text { Carrasco National Park }\end{array}$ & $\begin{array}{l}\text { MNCN 43103-5, 43108, MNCN- } \\
\text { DNA 5813, 5815, 5829, 6022, } \\
6027,6030,6057, \text { MNK-A 7235- }\end{array}$ & $\begin{array}{l}5813,5815,5818,5829 \\
5848,5882,6019,6022 \\
6027,6030,6039,6043\end{array}$ & $\begin{array}{l}\text { EU 712677-9, 712681, } \\
712684,712690,712697- \\
8,712700-1,712703\end{array}$ & This study \\
\hline & & $6,7238-9$ & $6057,6145,6166$ & $712705-6,712711-2$ & \\
\hline P. platydactylus & $\begin{array}{l}\text { Bolivia: Cochabamba: La Siberia, Carrasco } \\
\text { National Park }\end{array}$ & $\begin{array}{l}\text { MNCN 42993-5, 43001, MNK-A } \\
6589\end{array}$ & $3911-14,3918$ & EU712643-7 & This study \\
\hline P. platydactylus & $\begin{array}{l}\text { Bolivia: Cochabamba: road to Penstock } \\
\text { Pipeline, Carrasco National Park }\end{array}$ & MNCN 43106, MNK-A 7237 & 5870,6172 & EU712688, 712713 & This study \\
\hline P. platydactylus & $\begin{array}{l}\text { Bolivia: Cochabamba: Sehuencas, } \\
\text { Carrasco National Park }\end{array}$ & $\begin{array}{l}\text { MNCN 43003-6, 43091-2, } \\
\text { 43094-6, MNK-A 6613, 7223-5 }\end{array}$ & $\begin{array}{l}3929-3,5793,5802 \\
5812,5860,5880,5983 \\
6023,6062\end{array}$ & $\begin{array}{l}\text { EU192284, 712648-51, } \\
712673,712675-6, \\
712687,712689,712693, \\
712699,712707\end{array}$ & $\begin{array}{l}\text { Padial \& De la Riva (2009) } \\
\text { this study }\end{array}$ \\
\hline
\end{tabular}


Appendix 3 Continued.

\begin{tabular}{|c|c|c|c|c|c|}
\hline Species & Locality & Voucher & MNCN-DNA & GenBank & Source \\
\hline P. platydactylus & Bolivia: La Paz: Boqueron, Pilon Lajas & CBG 836-7, 839 & $6351,6370,6377$ & EU712716-8 & This study \\
\hline P. platydactylus & $\begin{array}{l}\text { Bolivia: La Paz: Huairuro, track btw. San } \\
\text { José and Apolo, Madidi National Park }\end{array}$ & $\begin{array}{l}\text { MNCN 43065, MNCN-DNA } \\
\text { 5850, 6012, MNK-A 7190-1 }\end{array}$ & $\begin{array}{l}5850,5900,6012,6034 \\
6041\end{array}$ & $\begin{array}{l}\text { EU712685, 712691, } \\
712696,712702,712704\end{array}$ & This study \\
\hline P. platydactylus & Bolivia: La Paz: Serranía Bella Vista & $\begin{array}{l}\text { MNCN 43147, 43224, MNK-A } \\
7272\end{array}$ & 6251,6255, IDIR 4121 & $\begin{array}{l}\text { EU712714, 712715, } \\
368901\end{array}$ & Padial et al. (2008a) \\
\hline P. platydactylus & $\begin{array}{l}\text { Bolivia: La Paz: Serranía del km 52, Sud } \\
\text { Yungas }\end{array}$ & $\begin{array}{l}\text { MNCN 43038-9, MNK-A 6609- } \\
10\end{array}$ & $4135-8$ & EU712668-71 & This study \\
\hline P. platydactylus & $\begin{array}{l}\text { Bolivia: Santa Cruz: Paredones del } \\
\text { Amboró, Amboró National Park }\end{array}$ & MNCN-DNA 5800 & 5800 & EU712674 & This study \\
\hline P. platydactylus & $\begin{array}{l}\text { Bolivia: Santa Cruz: road btw. Empalme } \\
\text { and Carahuasi }\end{array}$ & $\begin{array}{l}\text { MNCN 43009-10, MNK-A 6597- } \\
9\end{array}$ & $-3942-6$ & EU712652-6 & This study \\
\hline P. platydactylus & $\begin{array}{l}\text { Bolivia: Santa Cruz: Serranía Siberia, El } \\
\text { Empalme, Amboró National Park }\end{array}$ & $\begin{array}{l}\text { MNCN 43082, 43084, MNCN- } \\
\text { DNA 3919, MNK-A 7211-2, } \\
7161\end{array}$ & $\begin{array}{l}3919,5841,5858,5997 \\
6007,6072\end{array}$ & $\begin{array}{l}\text { EU192283, 712683, } \\
712686,712694-5, \\
712708\end{array}$ & $\begin{array}{l}\text { Padial \& De la Riva (2009), } \\
\text { this study }\end{array}$ \\
\hline P. platydactylus & Peru: Cusco: Pantiacolla & MHNC 4445 & 9484 & EU368880 & Padial et al. (2008a) \\
\hline P. platydactylus & $\begin{array}{l}\text { Peru: Puno: Quispicanchis Between San } \\
\text { Miguel and Marcapata }\end{array}$ & MNCN 43248 & 5524 & EU192255 & This study \\
\hline P. pluvicanorus & $\begin{array}{l}\text { Bolivia: Cochabamba: El Palmar, Carrasco } \\
\text { National Park }\end{array}$ & CBG 963 & 5774 & EU192242 & Padial et al. (2007) \\
\hline P. pluvicanorus & $\begin{array}{l}\text { Bolivia: Cochabamba: Sehuencas, } \\
\text { Carrasco National Park }\end{array}$ & CBG 92, 128-34, MNCN 43002 & $\begin{array}{l}3928,5735,5750,5754 \\
5761,5771-2,5778\end{array}$ & $\begin{array}{l}\text { EU192236-7, 192239-40, } \\
\text { 192243-6 }\end{array}$ & Padial et al. (2007) \\
\hline P. pluvicanorus & $\begin{array}{l}\text { Bolivia: Cochabamba: road to Penstock } \\
\text { Pipeline, Carrasco National Park }\end{array}$ & MNCN-DNA 6004 & 6004 & EU192247 & Padial et al. (2007) \\
\hline P. pluvicanorus & Bolivia: Santa Cruz: La Yunga de Mairana, & MNCN 43035, MNK-A 6623 & $4118-9$ & EU192238, 192241 & Padial et al. (2007) \\
\hline P. reichlei & $\begin{array}{l}\text { Amboró National Park } \\
\text { Bolivia: Cochabamba: Los Guácharos, } \\
\text { Carrasco National Park }\end{array}$ & MNCN 43012, MNK-A 6621 & $4084-85$ & EU192286-7 & This study \\
\hline P. reichlei & Bolivia: Pando: Bioceanica & NMP6V 72578/1-2 & 9476 & EU712719 & This study \\
\hline P. reichlei & $\begin{array}{l}\text { Peru: Cusco: } 5 \mathrm{~km} \text { from San Lorenzo to } \\
\text { Quince Mil }\end{array}$ & MNCN 43249 & 5542 & EU192288 & This study \\
\hline P. reichlei & Peru: Cusco: Pantiacolla & MHNC 4482 & 9487 & EU712720 & This study \\
\hline P. reichlei & $\begin{array}{l}\text { Peru: Puno: Entre Puerto Leguia y San } \\
\text { Gabán }\end{array}$ & IDLR 4779 & 20642 & EU192285 & This study \\
\hline $\begin{array}{l}\text { P. } \\
\text { rhabdolaemus }\end{array}$ & $\begin{array}{l}\text { Bolivia: Santa Cruz: La Yunga de Mairana, } \\
\text { Amboró National Park }\end{array}$ & MNCN 43036 & 4120 & EU192257 & Padial et al. (2007) \\
\hline $\begin{array}{l}\text { P. } \\
\text { rhabdolaemus }\end{array}$ & $\begin{array}{l}\text { Bolivia: Santa Cruz: road btw. Empalme } \\
\text { and Carahuasi }\end{array}$ & MNK-A 6628 & 3940 & EU192258 & Padial et al. (2007) \\
\hline $\begin{array}{l}\text { P. } \\
\text { rhabdolaemus }\end{array}$ & $\begin{array}{l}\text { Bolivia: Santa Cruz: San Juán Cantón, } \\
\text { Amboró National Park, } 2050 \text { m }\end{array}$ & AMNH A 165195 & - & AY843586 & Frost et al. (2006) \\
\hline P. samaipatae & $\begin{array}{l}\text { Bolivia: Santa Cruz: Km } 6 \text { Angostura- } \\
\text { Samaipata road }\end{array}$ & MNCN 42987-9, MNK-A 6626 & 3899-3902 & EU192289-92 & $\begin{array}{l}\text { Padial \& De la Riva (2009), } \\
\text { Padial et al. (2008a) }\end{array}$ \\
\hline P. toftae & $\begin{array}{l}\text { Bolivia: Cochabamba: Los Guácharos, } \\
\text { Carrasco National Park }\end{array}$ & MNCN 43025 & 4093 & EU192293 & Padial \& De la Riva (2009) \\
\hline $\begin{array}{l}\text { P. toftae } \\
\text { Oreobates } \\
\text { (outgroup) }\end{array}$ & Peru: Cusco: San Pedro, Marcapata Valley & MNCN 43246 & 5505 & EU192294 & Padial \& De la Riva (2009) \\
\hline O. cruralis & Bolivia: Santa Cruz: road to Bella Vista & MNK-A 7171 & 6098 & EU192295 & Padial et al. (2008a) \\
\hline $\begin{array}{l}0 . \\
\text { heterodactylus }\end{array}$ & $\begin{array}{l}\text { Bolivia: Santa Cruz: Cerro del Arco, } \\
\text { Serranía de Santiago }\end{array}$ & MNK-A 7175 & 6061 & EU192296 & Padial et al. (2008a) \\
\hline O. quixensis & $\begin{array}{l}\text { Bolivia: Pando: San Sebastián, Reserve } \\
\text { Tahuamanu }\end{array}$ & MNCN 43417 & 6216 & EU192297 & Padial et al. (2008a) \\
\hline
\end{tabular}

Abbreviations: AMNH A, Amphibian collection of the American Museum of Natural History (New York, USA); CBF, Colección Boliviana de Fauna (La Paz, Bolivia); CBG, Centro de Biodiversidad y Genética (Cochabamba, Bolivia); IdlR, Ignacio De la Riva's field series, MNCN, Museo Nacional de Ciencias Naturales (Madrid, Spain); MNCN-DNA, Museo Nacional de Ciencias Naturales's DNA and Tissue Collection (Madrid, Spain); MNK-A,Amphibian Collection, Museo de Historia Natural Noel Kempff Mercado (Santa Cruz de la Sierra, Bolivia); MHNC, Museo de Historia Natural, Universidad Nacional de San Antonio Abad del Cusco (Cusco, Peru); ZFMK, Zoologisches Forschunginstitut und Museum Alexander König (Bonn, Germany). 